\title{
Are Capital Inflows Expansionary or Contractionary in the Philippines?
}

Rogelio Mercado Jr.

TEP Working Paper No. 2116

December 2016

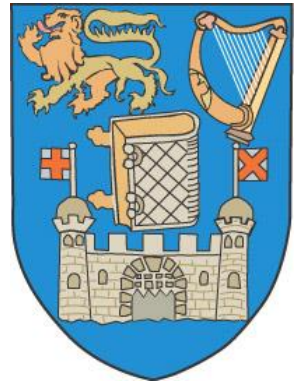

Trinity Economics Papers

Department of Economics

Trinity College Dublin 


\title{
Are Capital Inflows Expansionary or Contractionary in the Philippines?
}

\author{
Rogelio Mercado Jr.* \\ Northumbria University
}

December 2016

\begin{abstract}
This paper sets out to assess whether gross capital inflows to the Philippines are expansionary or contractionary in line with the model predictions and empirical findings of Blanchard et al. (2015). The results indicate that gross inflows are expansionary to output and credit growth. But contrary to the model predictions and empirical findings of Blanchard et al. (2015), we find that private bond inflows to the Philippines are expansionary. Bond inflows may have expansionary impact on output and credit growth if the exchange rate is managed, if the domestic capital market is underdeveloped, if the country receives small bond inflows, and if proceeds from debt issuance are channelled to productive investments. Similar to Blanchard et al. (2015), non-bond inflows have a positive overall impact on output and credit growth despite receiving relatively small foreign direct investment inflows.
\end{abstract}

Keywords: capital inflows, output growth, credit growth

JEL codes: F32, F41, F43

\footnotetext{
*Lecturer in Economics, Newcastle Business School, Northumbria University, Email: rogelio.mercado@northumbria.ac.uk The author is highly indebted to Philip R. Lane for his valuable guidance, comments and suggestions. The author is also grateful to Agustin Benetrix, Vahagn Galstyan, Hiro Ito, and Cedric Tille for their comments and suggestions on this paper.
} 


\section{Introduction}

Standard open economy models along the lines of Mundell (1963) and Fleming (1962) illustrate that capital inflows lead to currency appreciation, lower net exports and so are contractionary. However, more recent empirical studies in the boom-bust literature, including Caballero (2014) and MilesiFerretti and Tille (2011), tell another story. As capital flows to a country, it facilitates domestic credit boom. The conversion of foreign currency to domestic currency technically leads to expansion of domestic money supply putting downward pressure on domestic interest rates. As borrowing costs fall, investment and output increase. And so, capital inflows can be expansionary. But empirical evidence including those from Reinhart and Reinhart (2009), as well as policy dilemma faced by emerging economies indicate that capital inflows lead to currency appreciations, credit booms, and output increases. This could potentially lead to contractions, crises, and reversals of capital inflows. In short, empirics and practice point to an amalgamation of capital flow effects.

In response to this dichotomy of effects, Blanchard et al. (2015 and 2016) propose a portfolio choice model with two asset class. ${ }^{1}$ They assume two types of capital inflows, bonds and non-bonds. These two types of capital inflows are assumed to be imperfect substitutes such that there are separate interest rates for each. For bonds, it is the policy rate; while for non-bonds, it is the bank borrowing rate. Intuitively, bond inflows are linked to the policy rates as bonds are used as instruments in the conduct of open market operations. Non-bond inflows relate more to borrowing cost as they increase the supply of loanable funds in the financial market. The rationale for differentiating between bond and non-bond inflows is their varying impact on non-bond (borrowing) interest rate which pertains to the cost of financial intermediation. Bond inflows tend to increase the borrowing rate to counteract the expected currency depreciation following currency appreciation; whereas non-bond inflows decrease borrowing rate as the supply loanable funds in the financial markets increases. Blanchard et al. (2015) argues that for a given policy rate, bond inflows lead only to currency appreciation but an increase in borrowing rate and so are contractionary. In contrast, nonbond inflows lead to both currency appreciation and a decline in borrowing rate. Depending on which effect dominates, capital inflows maybe expansionary.

Testing their theoretical model using instrumental variable approach to examine the effect of various types of capital inflows on output and credit growth for 19 emerging countries, Blanchard et al. (2015) find that bond inflows have negative but insignificant sign, while non-bond inflows have positive and significant effect on output and credit growth ${ }^{2}$. However, using cross-country estimation to assess the impact of capital inflows on output hides the fact that countries attract different types of capital inflows and respond to them differently. For instance, the insignificance of bond inflows in their empirical test might be caused by differences in amounts of bond inflows coming in to their emerging economy sample and so would have different effects. For this reason, testing Blanchard's et al. (2015) model on an individual country basis is warranted.

Among the emerging economies included in the Blanchard et al. (2015) empirical test, we focus on the Philippines for the following reasons. First, output growth in the Philippines is largely driven by consumption growth. Net exports and investment account for lower share of output growth. In fact, Philippines relies less on foreign trade as source of growth in contrast to other countries like Indonesia and Malaysia which are commodity exporters, and Korea which is industrialized. Since the Philippines relies less on foreign trade, currency appreciation might not have strong contractionary impact on overall output growth (although overseas remittances do on the current account balance).

\footnotetext{
1 Throughout this paper, we cite Blanchard et al. (2015) as it is in their working paper version where they develop and test their model predictions.

2 Emerging economies include Brazil, Chile, Colombia, Czech Republic, Hungary, India, Indonesia, Israel, Korea, Malaysia, Mexico, Peru, the Philippines, Poland, Romania, Russia, Thailand, Turkey, and South Africa. Period covers 2000 onwards using annual data.
} 
Second, among the other economies in the sample, the Philippines is less open and attracts less foreign direct investments. Until now, several sectors of the economy are barred to foreign investors. Under such condition, one might expect that the expansionary effect of capital inflows on output growth in the Philippines will be weaker compared to other countries that are more open to foreign direct investments. Third, the Philippine central bank intervened in the foreign exchange market more so in the 1970s right up to mid-1997 in order to maintain a stable exchange rate. Having a managed exchange rate system weakens the link between capital inflows and currency appreciation. In summary, the Philippines offers an example of a small open economy that is vulnerable to external forces and faces monetary policy trilemma but at the same time relies less on foreign trade and foreign direct investments. These circumstances run contrary to its neighbours like Indonesia, Malaysia, and Thailand which are export-dependent and highly open to all types of foreign investments. For these reasons, this paper focuses solely on the Philippines.

Previous studies on capital inflows in the Philippines have focused on describing the patterns and policy responses. Few studies have look on the impact of capital inflows on output or components of output. Even in Lamberte (1995) and Yap (2008) there are no distinctions on whether capital inflows are expansionary or contractionary on output and credit growth, along the lines of Blanchard et al. (2015). It is this gap in the literature that this paper contributes to.

This paper asks the following questions. First, are capital inflows expansionary or contractionary on output and credit growth in the Philippines? This allows us to look at the overall impact of capital inflows on output and credit. Second, are bond inflows contractionary and are non-bond inflows expansionary? This tests the model of Blanchard et al. (2015) on whether bond inflows account for the contractionary impact of capital inflows on output and credit. Third, are different types of capital inflows expansionary or contractionary? If the approach of Blanchard et al. (2015) on differentiating between types of capital inflows to explain the contractionary or expansionary effect is the right way to go, we can then expect to see that different types of capital inflows could have the same expansionary or contractionary effects. For example, we expect foreign direct investment inflows to be expansionary and not contractionary. This somehow extends the literature in differentiating between types of capital inflows.

Understanding whether capital inflows are expansionary or contractionary has important implications for literature and policy. On literature, to reconcile the contrasting impact of capital inflows, Blanchard et al. (2015) develop a theoretical model that differentiates between different types of capital inflows. They argue that one type of capital inflows can be expansionary while the other could be contractionary. Using country case study approach will demonstrate that in some cases capital inflows that are expected to be contractionary might turn out to be expansionary, as in the case for the Philippines, as countries receive different amounts and respond to capital inflows differently. For instance, bond inflows going to productive sectors, such as utilities, mining, and real estate development could have expansionary impact on growth, while bond inflows used for the purpose of interest payments and portfolio diversification would not have any real effects on the economy and so will only lead to currency appreciation, which is contractionary for growth. Therefore, testing the model using a country case study will inform the literature under what conditions the model predictions are valid and whether or not differentiating different types of capital inflows is the right approach in reconciling different effects of capital inflows.

On policy, the main policy recommendation of Blanchard et al. (2015) is to attract expansionary nonbond inflows and control the contractionary bond inflows. But these policy implications might be a mistake for a country whose bond inflows are expansionary. More importantly, such policy implications based on theoretical model, would be counterproductive in developing emerging market bond markets which could be an alternative source of domestic financing from bank lending. 
Therefore, caution must be made in addressing the contractionary and expansionary impact of capital inflows using different types of inflows.

In order to address the questions set out in this paper, we use annual data on different types of gross capital inflows to the Philippines from 1977 to 2015 . We use the same variables as in the Blanchard's et al. (2015) empirical test. The variables include total inflows, bond inflows, non-bond inflows, foreign direct investment inflows, portfolio equity inflows, other debt inflows, foreign country growth, change in terms of trade, domestic policy rate, and foreign exchange reserves. However, unlike their empirical test, we do not instrument for capital inflows to the Philippines to address potential endogeneity issues. The reasons are as follows. First, previous studies have shown that capital inflows to the Philippines are largely driven by external factors. This suggests that output growth in the Philippines per se does not attract foreign investments. Second, finding a suitable instrument for bond inflows and public bond inflows in line with instrument choice of Blanchard et al. (2015) is extremely difficult as foreign purchases of public bonds depend on sovereign debt risks that vary across countries. For these reasons, we proceed with our empirical test using ordinary least squares estimation but interpret the results in the context of causation.

The results point to several important considerations in explaining the expansionary or contractionary impact of capital inflows to emerging economies. In the Philippines, bond inflows have expansionary impact on output and credit growth, particularly private bond inflows. This could be explained by the fact that the exchange rate is managed for most part of the sample period, bond market is relatively underdeveloped, bond inflows are small, and some proceeds from debt issuance are channelled to productive investments. In contrast, non-bond inflows have an overall positive effect on output and credit growth despite having restrictions on foreign direct investments. These findings clearly demonstrate that there is a lot to be considered in explaining why the impact of capital inflows in the standard open macro-economy model is at odds with policy experience of emerging economies.

This paper proceeds as follows. Section 2 provides theoretical motivation and empirical literature. Section 3 presents the empirical specification. Section 4 discusses the patterns and policy responses of capital inflows to the Philippines as well as data description. Section 5 discusses the baseline and sensitivity results. Section 6 offers concluding remarks.

\section{Conceptual Framework}

\subsection{Theoretical Motivation}

Standard open economy models along the lines of Mundell (1963) and Fleming (1962) indicate that capital inflows lead to currency appreciation which, in turn, lowers net exports and so are contractionary. Crucial to the Mundell-Fleming model is the assumption of perfect capital mobility, where domestic and foreign interest rates are equal such that any disequilibria between the two will trigger capital flows. For instance, a decline in foreign interest rate will lead to an imbalance between domestic and foreign rates. Given that foreign interest rate is now lower than domestic interest rate, this will trigger capital inflows to the domestic economy as it has higher interest rate. If uncovered interest rate parity condition holds, the decline in foreign interest rate, given a constant domestic interest rate and expected future exchange rate, the exchange rate will increase or will lead to currency appreciation. In turn, this appreciation will make domestic exports expensive relative to foreign products and so net exports and output will decline. In this case, capital inflows are contractionary. 
However, more recent empirical studies in the boom-bust literature, including Caballero (2014) and Magud et al. (2014), tell another story. As capital flows to a country, it triggers a domestic credit boom. A channel for this is that capital inflows will eventually have to be exchanged or converted to domestic currency. This technically leads to an expansion of money supply, which puts downward pressure on domestic interest rates. But lower interest rate will reduce the cost of borrowing, which will increase investment and output. In this case, capital inflows are expansionary. Empirical evidence including those from Reinhart and Reinhart (2009), as well as policy dilemma faced by emerging economies indicate that capital inflows lead to currency appreciations, credit booms, and output increases. This could potentially lead to contractions, crises, and reversals of capital inflows. In short, theory and empirics point to an amalgamation of capital flows effects.

In response to this dichotomy of capital flows effects, Blanchard et al. (2015) propose a portfolio choice model. They assume two types of capital inflows, bond and non-bond inflows. Bond inflows pertain to portfolio debt liabilities while non-bond inflows include foreign direct investment, portfolio equity and other investment liabilities of Financial Accounts of the Balance of Payments. These two types of capital inflows are assumed to be imperfect substitutes such that there are separate interest rates for both. For bonds, it is the policy rate, while for non-bonds, it is the nonbond interest rate which relates to the borrowing rate. Blanchard et al. (2015) argue that capital inflows act through both non-bond borrowing rate and the exchange rate as indicated in their general condition equations

$$
\begin{aligned}
& R_{N}=1+\frac{1}{6} s_{B}-\frac{1}{6} s_{N} \\
& E=1+\frac{1}{3} s_{B}+\frac{1}{6} s_{N} \\
& B_{F}-\bar{B}_{F}+N_{F}-\bar{N}_{F}=\frac{1}{2} \beta s_{B}+\frac{1}{2} \beta s_{N}
\end{aligned}
$$

where $R_{N}$ is the borrowing rate; $E$ is the exchange rate; $s_{B}$ stands for bond inflows; $s_{N}$ stands for non-bond inflows; $\bar{B}_{F}, \bar{N}_{F}$ are initial bond and non-bond foreign holdings; $B_{F}, N_{F}$ are foreign demand for domestic bond and non-bond assets; and $\beta$ is a coefficient.

Their model predicts that even if the policy rate (the rate on bonds) is given, both bonds and nonbond inflows lead to currency appreciation. However, both types of capital inflows have varying impact on non-bond interest rate. Bond inflows increase non-bond interest rate to offset the expected currency depreciation, following the appreciation due to capital inflows. Non-bond inflows decrease non-bond interest rate as the increase in non-bond inflows increases the supply of loanable funds in the financial market. The positive effect of lower borrowing rate on domestic demand may then offset the adverse effects of currency appreciation on external demand. Therefore, capital inflows need not, but may, be expansionary even for a given policy rate. It is this theoretical implication which this paper tests in the context of the Philippines.

\subsection{Empirical Literature}

The economics literature on capital flows is vast. There are several research areas dealing with various aspects of capital flows. One area pertains to the drivers of capital flows across countries. An overarching theme in this strand of the literature looks into factors that matter most for capital 
flows. These factors are broadly categorized as "push" factors that are external to an economy and "pull" factors that pertain to domestic macroeconomic fundamentals (Calvo et al. 1993 and 1996, Fernandez-Arias, 1996, and Chuhan et al. 1998). ${ }^{3}$ Another branch looks into the patterns of capital flows particularly during extreme episodes or crisis periods. For instance, Calvo (1998), Forbes and Warnock (2012a and 2012b), Ghosh et al. (2014) and Reinhart and Reinhart (2009) focus on episodes of sudden stops and capital bonanzas, while Broner et al. (2013) and Milesi-Ferretti and Tille (2011) look at the patterns of capital flows before, during, and after crises. These studies deal with the determinants and patterns of capital inflows as they have important implications on how best to harness and mitigate the advantages and disadvantages of capital flows.

Another important branch in the literature specifically looks at the impact of capital inflows on growth or development. Several studies have looked into whether financial openness leads to stronger growth in developing and emerging economies. For instance, Easterly (2000) finds that average growth rate among emerging countries remained stable at a low level despite a surge of capital flows in the 1990s. Rodrick (1998) shows using a cross-country analysis that financial openness is not associated with higher growth. Prasad et al. (2007) also find no evidence that an increase in foreign capital inflows directly boosts growth. In fact, some studies argue that developing countries that rely less on foreign capital seem to growth faster (Bosworth and Collins, 1999; and Prasad et al. 2007).

Several explanations have been put forth explaining the weak empirical support for financial openness on growth and development (World Bank, 2001). First, the high volatility of capital flows may negate their beneficial impact. Assessing the potential benefits of financial openness depends on what other factors are accounted for growth. In a panel data set-up, this could be dampened by the inclusion of dummy variables as controls. In a cross-sectional set-up, accounting for the volatility of capital inflows leads to a positive relation between growth and capital flows. Another explanation for the weak evidence is that capital flows may not be associated with more rapid growth when absorptive capacity is poor. This is the explanation of Lucas (1990) as he argues that not all developing countries exhibit high marginal productivity of capital. In fact, Martin and Taddie (2013) argue that capital inflows can cause adverse selection leading to an overall decline in productivity as less productive investments acquire funding via foreign capital inflows.

A clearer assessment of the impact of financial openness on growth is using a comparable stock or flow measure of financial openness and growth. For instance, Blanchard et al. (2015) assessed the impact of capital inflows on growth and credit using flow measures for 2000 to 2014. In effect, capital inflows are used as a flow measure for financial openness, while real GDP growth is used as a flow measure of output.

Distinct from Blanchard et al. (2015) is their focus on the expansionary and contractionary impact of capital inflows on annual growth and credit change. Standard macroeconomic models show that at a given interest rate, capital inflows lead to currency appreciation which lowers net exports and hence, have contractionary impact on output. However, actual experience of emerging economies point to another channel. Capital inflows can trigger domestic credit booms and so have expansionary impact on output growth and credit (Caballero 2014, and Magud et al. 2014). Using a theoretical model, Blanchard et al. (2015) show that bond inflows can be contractionary while nonbond inflows can be expansionary, depending on which effect dominates determines the overall impact of capital inflows on growth.

Using a cross-country pooled set-up for 19 emerging economies, Blanchard et al. (2015) find that non-bond inflows are expansionary for output growth, while bond inflows have negative

\footnotetext{
${ }^{3}$ See Koepke (2015) for detailed literature review on drivers or determinants of capital flows.
} 
insignificant sign, suggesting their potential contractionary effect. They also find that capital inflows have positive but insignificant impact on domestic credit, which is contrary to their model predictions. But the theoretical model and empirical test of Blanchard et al. (2015) leaves room for further research. Using cross-country pooled set-up may lead to insignificant results, such as their insignificant estimated parameter for bond inflows, as individual countries respond differently to capital inflows, possibly due to differences in the amount of capital inflows they receive, their absorptive capacity, policy responses to capital flows, and level of financial development. Therefore, in order to validate Blanchard's et al. (2015) model, individual country studies must be considered.

Country case studies in the context of capital inflows have been conducted in the past. For instance, Chamon and Garcia (2016) look into the impact of capital controls for Brazil and find mixed evidence on the effectiveness of capital controls. The authors show that capital controls had some success in segmenting domestic market from the international financial market, but they did not lead to significant changes in the exchange rate. Various papers have also used country-case studies to look at the patterns, effects and policy responses of individual countries in managing capital inflows. The Asian Development Bank Institute commissioned several studies examining how individual Asian economies managed their capital inflows. These include those from Chow (2008) for Singapore, Foong (2008) for Malaysia, and Sangsubhan (2008) for Thailand.

For the Philippines, several authors have already looked at the patterns, determinants, and impact of capital flows. Gochoco-Bautista and Canlas (2002) show that domestic interest rates would have been higher in the absence of capital inflows to the Philippines and that money demand would also have been higher. Gonzales (2008) highlights the external factors, such as low global interest rates, trigger capital inflows to the Philippines, and how the Philippine central bank manages capital inflows. IMF (2015) finds that capital inflows to the Philippines are primary driven by global factors such as global risk aversion and global interest rates and that non-FDI inflows are highly correlated with domestic demand. Lamberte (1995) finds that net portfolio inflows from 1986 to 1994 to the Philippines have been expansionary for domestic investment. Intal and Llanto (1998) argue that the worsening of terms of trade in the Philippines in the 1990s was partly due to the real appreciation of the Philippine peso in line with surging capital inflows. Finally, Yap (2008) concludes that the impact of capital inflows on consumption, investment, and government expenditure appears insignificant based on impulse response functions from a vector error correction model.

However, these country studies focusing on the Philippines do not specifically address whether capital inflows are expansionary or contractionary for output and credit growth in line with Blanchard's et al. (2015). Conversely, the model predictions of Blanchard et al. (2015) have not been tested in an individual country-case study. Focusing on one country case study could potentially shed light under what conditions Blanchard's model predictions hold true or not, while taking into account a country's peculiarities. It is this gap in the literature which this paper addresses.

\section{Empirical Specification}

In order to address the questions set out in this paper, we follow the specification of Blanchard et al. (2015) for one country, the Philippines, using annual data from 1977 to 2015 . Specifically, we estimate the equation

$$
Y_{t}=\alpha_{0}+\beta_{1} X_{t}+\beta_{2} Y_{t-1}+\beta_{3} Y_{t}^{*}+\beta_{4} \Delta T O T_{t}+\beta_{5} P R_{t}+\beta_{6} F X R_{t}+\varepsilon_{t}
$$

where $Y_{t}$ refers to annual output or credit growth (change in domestic credit as percent to GDP). $X_{t}$ refers to different types of capital flows. We first include total gross capital inflows as percent of 
GDP, and then we use bond (portfolio debt inflows) and non-bond split. Unlike Blanchard et al. (2015), we also disaggregate bond inflows into private and public bond inflows as percent of GDP, and then split non-bond inflows into foreign direct investment, portfolio equity, and other debt (investment) inflows. Similar to Blanchard et al. (2015), we include control and policy variables. For controls variables, we include lagged dependent variable $Y_{t-1}$, growth of major trading partner country $Y_{t}^{*}$ (United States), and change in terms of trade $\triangle T O T$. For policy variables, we include domestic interest rate, $P R_{t}$, and foreign reserves as percent of GDP, $F X R_{t} . \varepsilon_{t}$ is the error term.

Unlike Blanchard et al. (2015), we look into different categories of output and credit growth as dependent variables. For output growth, we look into the tradable versus non-tradable sector growth. Differentiating between the two will test whether capital inflows are contractionary for tradable sector growth due to exchange rate appreciation and expansionary for non-tradable sector. For credit growth, we look into credit provided by the banking sector to both public and private sectors to assess which sector capital inflows lead to credit expansion.

In estimating Equation (4), we use different specifications pertaining to different types of gross capital inflows. ${ }^{4}$ First, we show the impact of total gross capital inflows on output and credit including control and policy variables. Second, we split total gross capital inflows into bonds and non-bond inflows. Bond inflows pertain to gross portfolio debt inflows, while non-bond inflows include gross foreign direct investment inflows, gross portfolio equity inflows, and gross other investment inflows (other debt). This is in line with theoretical model of Blanchard et al. (2015).

Third, we look into whether there is difference between public and private bond inflows. In Blanchard et al. (2015), they highlight the contractionary impact of bond inflows at given policy rate but they did not differentiate between public and private bond inflows. In this paper, we test whether the contractionary impact holds for both private and public bond inflows. The rationale for separating the two is to test whether private bond inflows could have expansionary effect as corporations might be issuing bonds to finance business expansions, and so private bond inflows might have expansionary impact on growth. On the other hand, public bonds, particularly sovereign bonds, could be issued to finance government interest payments or for portfolio diversification motive and so they might not have an impact on overall growth.

Fourth, we decompose non-bond inflows into foreign direct investment inflows, portfolio equity inflows, and other debt inflows; and include bond inflows. This provides a disaggregated look into the impact of different types of capital inflows. Lastly, we decompose bond inflows into public and private bond inflows and include the components of non-bond inflows, which are foreign direct investment inflows, portfolio equity inflows, and other debt investment inflows. This will show the expansionary or contractionary impact of the most disaggregate type of gross capital inflows.

Similar to Blanchard et al. (2015), we include control and policy variables in Equation (4). For control variables, lagged dependent variable is included to capture growth dynamics. A positive sign implies high domestic growth momentum, which could attract more foreign investments. U.S. GDP growth is included to account for domestic growth in the Philippines' major trading partner. A significant estimated parameter will suggest strong economic links between the two countries and indicate the importance of U.S. investment in the Philippines. Change in terms of trade is included to capture the effect of currency movement on the trade balance. A negative sign implies that currency appreciation leads to worsening of trade balance due to the loss of export competitiveness. For policy variables, policy rate is included to account for the impact of interest rate on growth; while

\footnotetext{
${ }^{4}$ Since our independent variables change given different types of capital inflows, we run ordinary least squares regression instead of seemingly unrelated regression.
} 
foreign reserves are added to capture the impact of foreign exchange sterilization on growth. Blanchard et al. (2015) argue that full sterilization of bond inflows have no effect on output and credit growth as it only facilitates change of bond ownership between domestic and foreign investors. But for non-bond inflows, sterilization leads to a greater decline in borrowing rate which further increases credit and output growth.

We estimate Equation (4) using ordinary least squares to show the causation between output and credit growth with capital inflows. Ideally, in establishing whether capital inflows are expansionary or contractionary in the Philippines, we should be using an instrumental variable approach following Blanchard et al. (2015) so as to address potential endogeneity. For instrument variable choice, we can instrument different types of gross capital inflows to the Philippines with the corresponding aggregate capital inflows to Indonesia, Malaysia and Thailand, and instrument policy rate and foreign reserves with U.S. policy rate and a measure of global risk aversion (VXO), respectively. However, we limit our estimation results to ordinary least squares for the following reasons.

First, for an instrumental variable approach to be appropriate, we need to have valid instruments. In this regard, we can follow the approach of Blanchard et al. (2015) in using the aggregate capital inflows to selected emerging economies as instruments for capital inflows to the Philippines. For example, total gross capital inflows to the Philippines can be instrumented using aggregate total gross capital inflows to Indonesia, Malaysia, and Thailand as we expect the total gross inflows pattern to these countries are highly correlated to that for the Philippines. But capital inflows to those countries do not influence output and credit growth in the Philippines. As such, it would then be a valid instrument. However, the Angrist-Pischke multivariate F-test statistic in the first stage for bond inflows is 1.03 which suggests very weak nature of the instrument. This is corroborated by the insignificant estimated parameter from the bivariate regression between bond inflows to the Philippines and emerging East Asia bond inflows, suggesting weak correlation between endogenous and instrument variables.

Furthermore, breaking down bond inflows to private and public bond inflows, we find that the estimated parameter for public bond inflows is also insignificant. This is expected as public bond inflows differ from one country to another as foreign purchases of public bonds are highly responsive to default probability or fiscal position of the issuing country. Consequently, we do not have a strong instrument for bond and public bond inflows to the Philippines following the approach of Blanchard et al. (2015). ${ }^{5}$

Second, IMF (2015) and Yap (2008) establish that capital inflows to the Philippines are primary driven by push or global factors including global risk aversion and interest rate differentials. Given their findings, it would be reasonable to assume that gross inflows to the Philippines can be treated as exogenous such that Philippine output and credit growth have no impact on capital flows going to the country. This assumption is in line with previous studies including those from Gochoco-Bautista

\footnotetext{
${ }^{5}$ We run a test using instrument variable approach following Fuller's (1977) modified limited-information maximum likelihood (FLIML) estimation for several reasons. First, since we have small sample size, we cannot use generalized method of moments as it could lead to biased estimates (Baum et al. 2007, Hayashi 2000, and Wooldridge 2001). Second, two-stage least squares (TSLS) would also be inappropriate given that bond, public bond, and foreign reserves have weak instruments and so would yield biased estimates (Anderson et al. 1982). Third, although limited-information maximum likelihood (LIML) would be an alternative, unfortunately, it does not to have finite sample moments of higher order (Hahn et al. 2004). Fuller's (1977) modified limited-information maximum likelihood (FLIML) addresses small sample size with weak instruments and has finite sample moments (Hahn et al. 2004). In effect, the FLIML modifies the LIML estimator by subtracting from LIML root, $\lambda_{0}$, a number which is asymptotically negligible as the sample size increases (Davidson and MacKinnon 1993; and Kadiyala and Oberhelman 1992). We used $\alpha=4$ as it has smaller root mean square (better model fit) and instrument capital inflows to the Philippines using their corresponding aggregate inflows to Indonesia, Malaysia, and Thailand. The results indicate that total gross inflows to the Philippines have expansionary impact on both output and credit growth. Similar to the baseline results, we find non-bond inflows have expansionary effect on output and credit growth, while private bond inflows have expansionary effect on credit. FDI inflows are insignificant and other debt inflows are significant and positive for credit growth, but not for output growth. Likewise, foreign reserves still have contractionary impact on credit. Overall, the key findings from the baseline estimation hold when we use FLIML estimation. The results are available upon request.
} 
and Canlas (2002) and Gonzales (2008) where they argue that capital inflows to the Philippines are driven by global or external factors including global investor sentiment, global liquidity, and global interest rate. Given these two points, we proceed using the OLS results in establishing causation between output and credit growth and gross capital inflows to the Philippines.

\section{Data Sources and Stylized Facts}

\subsection{Capital Flows to the Philippines}

Before addressing whether capital inflows are expansionary or contractionary in the Philippines, we first look at an overview of the patterns of different types of capital inflows to the country for the period of 1977-2015. Figure 1 presents total gross and net inflows. Figures 2 and 3 split total gross inflows to bond and non-bond gross inflows (Figure 2) as well as the breakdown of different types of non-bond gross inflows (Figure 3). Figure 4 compares total gross inflows to the Philippines as well as the aggregate gross inflows to Indonesia, Malaysia and Thailand, which we denote as EA inflows. Data on capital inflows are expressed as percent of nominal GDP in US dollars and are taken from the International Monetary Fund's Balance of Payments Statistics. We use data from the IMF instead those from national sources or from the Bangko Sentral ng Pilipinas as we want to be consistent with international classification of different types of capital inflows. ${ }^{6}$

Figure 1 illustrates the pattern of gross and net inflows. We note several observations. First, notice that the magnitude or size of gross and net inflows is roughly similar in the 1970s and 1980s. This implies that domestic-driven gross capital outflows are relatively small compared to foreign-driven gross capital inflows, such that the net inflows and gross inflows are roughly the same in magnitude. ${ }^{7}$ But starting in 1990s, we see a divergence between gross and net inflows reflecting the fact that domestic-driven flows have been increasing in line with capital account liberalization measures implemented in the early 1990s.

Second, the pattern of gross inflows clearly reflects global macroeconomic conditions. Gross inflows amount to more than 5 percent of GDP in the late 1970's, mostly driven by foreign bank inflows caused by petrodollar recycling in the 1970s. However, there was a clear reversal of foreign gross inflows in the early 1980's as the Philippines experienced sovereign debt crisis and massive capital flight triggered by the increase in global interest rates which made debt interest payment burdensome. This pattern is similar in severity as those experienced by Latin American and other economies during the debt crisis of 1980s. Nonetheless, the recovery from the economic collapse of 1983-1985 has been slow until the late 1980's which can be seen in the tepid foreign inflows during the late 1980's. It was only in the early 1990's to mid-1990's when the Philippines experienced an unprecedented surge in gross inflows following the implementation of capital account liberalization measures in 1991 and the return of Philippine assets in international capital markets following the end of debt moratorium imposed by the IMF stabilization programme. But this surge in gross inflows is in line with those experienced by other emerging economies in the mid-1990s, such that the huge inflows to the Philippines are not driven by country-specific factors.

However, the surge was short-lived due to the Asian financial crisis of 1997-98. Gross inflows have been smaller and more volatile in 2000s. Given the low risk aversion and low global interest rate, the Philippines witnessed another episode of surging gross inflows right before the global financial crisis of 2008-09. At the height of the last financial crisis, there was a reversal of foreign-driven gross

\footnotetext{
${ }^{6}$ Earlier data on Philippine capital account use the convention of inflows and outflows to pertain to the direction on gross flows. As such, we cannot differentiate between domestic and foreign resident driven inflows.

${ }^{7}$ Values on gross inflows and net inflows for 1983 to 1985 are very similar suggesting that gross outflows are roughly zero. However, this hides the fact that there was a huge capital flight out of the country in line with the economic collapse and debt crisis the country experienced in the early 1980's. Said capital flight is recorded under net errors and omissions of the Balance of Payments Statistics.
} 
inflows, but then capital inflows quickly returned to the pre-crisis level in late 2009. Again, this episode of surging gross inflows, following the global financial crisis, is not unique to the Philippines. Other emerging countries also experienced such massive return of foreign capital driven by very low interest rates in advanced economies. It is around this time that policy makers in emerging economies confront the adverse effects of unfretted gross inflows leading to currency appreciation and asset price inflation, which could have exacerbated financial vulnerabilities in emerging markets once global interest rates begin to rise. Overall, Figure 1 tells a story that gross capital inflows in the Philippines have been driven largely by external factors.

Figure2 splits total gross inflows into bond and non-bond inflows. Non-bond inflows clearly follow the pattern of gross inflows, suggesting that bond inflows have been very small relative to other types of gross inflows. In fact, bond inflows have only started to increase in the 1990s when the Philippines started floating public debt instruments in the international capital markets following capital account liberalization measures and the debt restructuring under the Brady plan. Although bond inflows have been very small throughout the late 1970s to early 1990s, there were still bond inflows going to the private sector. The private sector bond inflows go to not only private entities but also quasi-private entities or state-owned enterprises.

Figure 3 illustrates the pattern for different types of gross inflows. The dominant type of flows is other debt inflows or other investment liabilities. These are dominantly bank inflows. There are two episodes of strong other debt inflows. The first occurred in the late 1970s in line with government borrowing in the 1970s. The second occurred in the early to mid-1990s. The second episode is primary caused by domestic banks facilitating private sector foreign borrowing. Notice that FDI inflows have been comparatively small compared to other types of inflows. For portfolio equity inflows, the Philippines received a significant amount of foreign inflows of this type in the mid1990s. This is consistent with the general pattern of increasing portfolio inflows to emerging economies in the mid-1990s (Calvo et al. 1993 and 1996, Lamberte 1995 and Gonzales 2008).

Figure 4 shows aggregate gross inflows to Indonesia, Malaysia, and Thailand. The Philippines exhibits a broadly similar pattern such that the correlation between aggregate gross inflows to these countries and the Philippines is very high. But there are marked differences. First, the Philippines had more inflows in the late 1970s in line with its foreign borrowing in the 1970s that led to a debt crisis in the early 1980s unlike Malaysia and Thailand. Second, the Philippines received larger gross inflows prior to the Asian financial crisis. However, this masks the fact that the Philippines received smaller inflows for more than a decade. In other words, the Philippines is a late recipient of gross inflows in the 1990s which shielded it from the worst impact of the Asian financial crisis. Third, gross inflows to the Philippines came in tune with regional inflows around 2004-2005, reflecting low global risk and interest rate setting.

\subsection{Policy Responses to Capital Inflows to the Philippines}

The patterns of gross capital inflows, discussed in the previous section, have been influenced mainly by global factors. In response to gross inflows, several policy measures were undertaken to try to limit the destabilizing consequences of gross inflows to the Philippines. Specifically, policies implemented in the mid-1990s and in 2000s were geared toward mitigating currency appreciation and encouraging outward investments. Measures in place from 1987 to 1997 are broadly grouped into four categories (Lamberte 1995 and Yap 2008).

The first measure involves the reduction of foreign currency supply by cutting back requests for loan rescheduling under the Paris Club debt program. In addition, the Bangko Sentral ng Pilipinas (BSP) also increased allowable outward investment that can be sourced from the banking system and 
lifted restrictions on the repatriation of foreign investments made under the debt-to-equity conversion program. Second, to increase the demand for foreign currency, the central bank engaged in sterilized intervention. It did so by buying dollars in the foreign exchange market and then selling government securities in its portfolio to prevent money supply from increasing. This has been the standard sterilization procedure undertaken by the central bank. Third, the BSP instituted several measures to lower the cost of production of exporters to maintain their competitiveness. Specifically, they allowed exporters access to foreign currency denominated loans offered by foreign currency deposit units (FCDUs). Lastly, as prudential measure, the central bank reduced oversold position of banks to prevent banks from speculating in the foreign exchange market.

Following the Asian financial crisis of 1997-98, the BSP instituted regulatory and supervisory reforms to improve risk management, strengthen regulatory framework, and promote transparency. Some of these measures include following international data dissemination standards, compliance with international standards and codes, and participation in the IMF-World Bank Financial Sector Assessment Program. Apart from these measures, the BSP continued to implement measures that reduced the supply of foreign exchange inflows and increased the demand for foreign currency. But in addition to these standard measures, the monetary authority has undertaken new measures to encourage outward investments to reduce capital inflows and reserve accumulation.

Among these measures, the most visible policy response undertake by the central bank in response to capital inflows is its sterilized intervention in the foreign exchange market. Yap (2008) argues that intervention had become stronger after the Asian financial crisis when the Philippine peso was allowed to float more freely in the foreign exchange market. This currency intervention was conducted to ease sharp fluctuations in the exchange rate (Gonzales, 2008) in the post-Asian crisis period as shown in Figures 5 and 6. Gochoco-Bautista and Canlas (2002) find that for the period 1980 to 2000 , the exchange rate remained very stable while monetary growth and interest rate exhibited large variability, suggesting currency intervention. Lamberte (1995) estimates the offset coefficient between domestic and foreign assets, and finds that the offset coefficient is -0.88 , which is very close to -1 , suggesting inefficient sterilization measure.

However, the sterilization intervention of the central bank led to higher domestic interest rate, particularly in the early to mid-1990s. As pointed out by Gochoco-Bautista and Canlas (2002), the mopping up activity of the central bank kept domestic interest rate higher than it would have been without intervention. Given that there are few domestic firms who can tap the international market, the higher interest rate caused domestic firms to channel their foreign borrowing through domestic banks (Intal and Llanto, 1998). This facilitated currency and maturity mismatches in the run up to the Asian financial crisis of 1997-98. However, as a latecomer in the international financial market, the degree of foreign bank lending and currency and maturity mismatches are less pronounced that in other crisis-hit economies in the region. Nonetheless, the private sector has been hardly hit by the crisis due foreign over-borrowing in the early to mid-1990s.

\subsection{Data Sources}

To assess the impact of capital inflows on output and credit growth in the Philippines, we focus on gross capital inflows as we want to assess the impact of foreign-driven inflows into the economy. Using net capital inflows would include domestic-driven inflows whose pattern can be symmetric or asymmetric with respect to foreign-driven inflows. ${ }^{8}$ For this reason, this paper focuses on gross capital inflows which pertain to foreign resident inflows into the Philippines.

\footnotetext{
${ }^{8}$ For instance, using net inflows hides the huge decline in net capital inflows in 1983-1985 as domestic investors engage in capital flight recorded in the net errors and omissions. Using gross inflows would then just focus on the foreign-driven capital outflows during the period. Nonetheless, as sensitivity test, we also look into the impact of net capital inflows to the Philippines.
} 
Data on gross capital inflows are taken from the International Monetary Fund's Balance of Payment Statistics following Manual 6. The values are expressed as percentage of nominal GDP, both in millions US dollar. Nominal GDP in US dollars is taken from International Monetary Fund's International Financial Statistics. Data for both are available on an annual basis starting 1977 to $2015 .{ }^{9}$ Gross inflows pertain to foreign direct, portfolio equity, portfolio debt, and other investment liabilities of Balance of Payments Statistics. We split bond inflows into public and private bond inflows based on reporting sector. Public bond inflows pertain to portfolio debt liabilities of the central bank and general government, whereas private bond inflows refer to portfolio debt liabilities of depository taking corporations excluding central bank and other sectors. ${ }^{10}$

For dependent variables, data on output growth refers to the year-on-year change of real GDP in billions of Philippine peso from 1977-2015 taken from World Bank's World Development Indicators Database. Growth of tradable sector includes agriculture and manufacturing sectors; while nontradable includes non-manufacturing industry and services sectors. Data on credit growth pertains to the change in domestic credit measured as the difference between current and previous year's domestic credit as percentage of nominal GDP in billions Philippine Peso, from 1977-2015 taken from International Monetary Fund's Monetary Survey. Domestic credit, specifically, pertains to claims of other depository corporations.

For growth control variables, we include lagged output or credit growth, growth rate of major trading partner (United States), and the change in terms of trade. Data on U.S. output growth are taken from World Bank's World Development Indicators Database. The change in terms of trade is the difference between current and previous year's terms of trade index. Data on terms of trade is taken from World Bank's World Development Indicators Database and refers to Net Barter Terms of Trade Index for 1980 onwards using 2000 as base year. For 1976 to 1979, the data was derived from the Terms of Trade Index of the National Bureau of Economic Research (NBER). For policy control variables, we include both Philippine policy rate and foreign reserves. Data on Philippine policy rate is in percent per annum taken from the International Financial Statistics of the International Monetary Fund, while data on foreign reserves refer to reserve asset as percent of nominal GDP in US dollar millions.

\section{Empirical Analysis}

\subsection{Baseline Results}

Tables 1 to 3 present the OLS estimates for the impact of capital inflows on output and credit growth. Columns (1) and (6) include total gross inflows for both output growth (1) and credit change (6). Columns (2) and (7) differentiate between bond and non-bond inflows. Columns (3) and (8) split bond inflows to private and public bond inflows along with non-bond inflows. Columns (4) and (9) disaggregate non-bond inflows to FDI, portfolio equity and other debt inflows along with bond inflows, while Columns (5) and (10) differentiate all types of capital inflows. Table 4.1 focuses on output and credit growth. Table 2 breaks down output growth into tradable and non-tradable sector growth, and Table 3 splits credit change to public and private sector credit. Tables 1 to 3 indicate that we have 39 observations corresponding to annual data from 1977 to 2015 , and relatively good

\footnotetext{
${ }^{9}$ Given the volatile nature of quarterly gross capital inflows, data in this chapter focus on annual gross capital inflows. Furthermore, quarterly output and credit growth are also volatile as they are subject to seasonality effects. Using more volatile higher frequency data on output and credit growth and capital inflows might capture more noise in the data and, hence, lead to inconsistent results. Nonetheless, we run a sensitivity test using quarterly data to assess whether the baseline findings hold at higher frequency data. The results are discussed in Section 5.2.

${ }^{10}$ State-owned corporations are classified under private bond inflows.
} 
model fit given by the R-squared. The results on capital flows will first be discussed, followed by the control variables, and then policy variables.

Tables1 to 3 provide clear evidence on the expansionary impact of gross capital inflows on output and credit growth. Total gross inflows have positive and significant effect on both output growth and credit change as illustrated in specification (1). Specifically, a one percent increase in total gross inflows to GDP increases output growth by 0.3 percent and credit growth by 0.9 percent. This finding clearly indicates that capital inflows have an overall positive effect on output and credit in the Philippines. This result holds for both tradable and non-tradable sector growth. Literature on capital inflows shows that capital inflows have expansionary impact on non-tradable sector growth at the expense of tradable sector growth due to currency appreciation (Benigno et al., 2015; Calvo et al., 1993; and Reinhart and Reinhart 2009). However, Table 2 indicates that gross inflows have expansionary impact even for the tradable sector in the Philippines despite the Philippine peso being overvalued prior to 1997. A possible explanation for this is that capital inflows to the Philippines help in the expansion of the tradable sector by providing additional source of financing for both agricultural and manufacturing sectors. Table 3 shows that total gross inflows have expansionary effect on banking sector credit to private sector, but not for the public sector.

Across types of capital inflows, Tables 1 to 3 specifications (2), (4), (7) and (9) illustrate that bond inflows have positive but insignificant effect on output growth but positive and significant impact on credit growth, particularly for the private sector (Table 3 ). These results are inconsistent with Blanchard's et al. (2015) model and empirical results. Their estimates show that bond inflows have negative but insignificant impact on output growth, indicating potential contractionary effect in line with their model predictions. In contrast, Tables 1 and 2 indicate that bond inflows have positive but insignificant effect on output growth.

There are several plausible explanations for this. First, the contractionary impact of bond inflows on output growth assumes a more flexible exchange rate. In fact, in Blanchard et al. (2015), they cover the period starting 2000 when most emerging economies adapted a more flexible exchange rate regime. In this paper, the period coverage begins in 1977 when the Philippines have a managed exchange rate regime, which end in the Asian financial crisis of 1997-98. Under such condition, the channel in which capital inflows lead to currency appreciation would be weak. Hence, we do not see the contractionary impact of bond inflows on output. Even accounting for foreign exchange intervention, our estimates indicate that foreign reserves are insignificant for output growth. A related explanation would be that under a fixed or managed exchange rate regime, capital inflows could be larger and more expansionary as having a fixed or managed exchange rate acts as a guarantee for foreign investors, in line with the findings of Magud et al. (2014). Another explanation would be that bond inflows to the Philippines are relatively small (on average 0.8 percent of GDP for 1977 to 2015). This reflects that fact that debt markets in the Philippines are underdeveloped. As such, bond inflows would be too small to have significant impact on the exchange rate for it to be contractionary. Lastly, it is possible that bond inflows can be expansionary depending on whether the debt inflows go to productive investments. Lamberte (1995) argue that net portfolio inflows, mostly bond inflows, from 1986 to 1994 have positive effect on investment in the Philippines. This concurs with the results presented in Tables 1 to 3 .

Similar to Blanchard et al. (2015), bond inflows have positive sign for credit growth but unlike their estimates and theoretical predictions, the results in Tables 1 and 3 are significant. For instance, a one percent increase in bond inflows to GDP leads to a credit increase of around 1.5 percent of GDP in Table 1. A possible explanation on why bond inflows can be expansionary to credit is that bond inflows and other types of capital inflows might not necessary be imperfect substitutes. In the Blanchard et al. (2015) model, bond and non-bond inflows are treated as imperfect substitutes so 
that capital inflows can potentially affect the return on non-bonds at a given rate on bonds, which is assumed to be the policy rate. This assumption, although valid, could be simplistic as in some cases both bond and non-bond inflows can in fact complement each other. For instance, both public and private sectors can finance expansions by issuing bond and/or borrowing from the international financial market through the domestic banking system. Intal and Llanto (1998) described the channel through which bond inflows can increase domestic credit. Given that the Philippines have undergone significant capital account liberalization in the early 1990's, very few domestic firms tapped international foreign capital markets. The route taken by domestic firms in the Philippines is through foreign borrowing or through issuance of bond. Both have been coursed through domestic banks which increase private sector credit.

As Tables 1 to 3 illustrate, bond inflows have expansionary effect on credit change in the Philippines. Disaggregating bond inflows to private and public sectors allows us to know which inflows are expansionary or contractionary. Specifications (3), (5), (8) and (10) in Tables 1 to 3 clearly indicate that private sector bond inflows account for the expansionary effect of bond inflows to output and credit growth. In fact, most of the estimated coefficients in Tables 1 to 3 for private bond inflows have positive sign, and most are significant expect for Table 2, where private bond inflow is only expansionary for tradable sector growth in specification (5). In contrast, public bond inflows mostly have negative but insignificant effect on output growth and more so for credit change. This indicates that public sector bond inflows could potentially be the type of capital inflows that is contractionary. The expansionary impact of private bond inflows can be explained by the fact that foreign purchases or sales of private sector bonds come mostly from utilities, real estate, manufacturing, mining and banking sectors. Debt issuance of these sectors would have expansionary effect on output and can be coupled with domestic financing, thereby increasing bank credit.

Non-bond inflows have expansionary impact on output and credit growth as shown in specifications (2), (3), (7) and (8) in Tables 1 to 3. A one percent increase in non-bond inflows to GDP increases output growth by 0.3 percent and credit growth by 0.7 percent. The results hold for the tradable and non-tradable sector growth (Table 2) and domestic credit to private sector (Table 3 ). This finding is consistent with the model predictions of Blanchard et al. (2015). These results suggest that the contractionary impact of capital inflows via exchange rate appreciation is offset by the significant reduction in domestic returns on non-bonds, leading to an overall expansionary impact. GochocoBautista and Canlas (2003) find that in the absence of capital inflows to the Philippines, domestic nominal interest rates would have been substantially higher. Hence, this supports the model predictions of Blanchard et al. (2015).

Looking at different types of non-bond inflows in Tables 1 to 3 specifications (4), (5), (9), and (10), other debt inflows have positive and significant impact on output growth both for tradable and nontradable sector growth and credit change to the private sector. A one percent increase in other debt inflows to GDP increases output growth by around 0.3 percent and credit growth by around 0.5 percent. Foreign direct investment inflows have positive but insignificant impact. This runs contrary to the empirical test of Blanchard et al. (2015), where they find a positive and significant impact of FDI gross inflows on output and credit growth for a sample of 19 emerging countries including the Philippines. But this result is not surprising given that the Philippines has several existing restrictions on foreign direct investments and so receives less FDI inflows compared to other countries in the region. Lastly, portfolio equity inflows have negative and insignificant effect.

Among the control variables, we find evidence that output growth in the United States significantly increases output growth in the Philippines, even across tradable and non-tradable sectors. However, we do not find evidence of significant effect of U.S. credit growth on Philippine credit growth. Both lagged dependent variable and change in terms of trade are insignificant. Although both control 
variables are insignificant, they show the correct sign. Lagged dependent variable has positive sign, implying growth momentum. Change in terms of trade has negative sign across specifications, suggesting the contractionary impact of currency appreciation due to loss of export competitiveness.

For the policy variables, Tables 1 to 3 indicate that policy rate significantly reduces output and credit growth in the Philippines. For instance, a one percent per annum increase in domestic policy rate lowers output growth by 0.5 percent and credit growth by 0.4 percent. This result is both expected and consistent with Blanchard et al. (2015). In contrast, we find evidence that foreign reserves, which serve as proxy for foreign exchange sterilization measure, significantly lower credit growth, particularly credit to the private sector. This finding is consistent with the empirical test of Blanchard et al. (2015) but at odds with their model predictions. In their model, to leave the exchange rate constant given non-bond inflows, non-bond returns must significantly fall thereby intensifying the expansionary impact of capital inflows on output and credit growth. However, the contractionary impact of foreign exchange sterilization is in line with the actual experience of emerging countries. For instance, in the Philippines, surging capital inflows, particularly in the early to mid-1990's, were sterilized with higher domestic lending rate to keep the exchange rate stable right up to the Asian financial crisis. As such, domestic bank lending rates remained relatively high in the Philippines, compared to other countries in the East Asian region. This triggered private sector foreign overborrowing via the domestic banking sector.

Taken together, these results imply that non-bond inflows have significant expansionary impact on both output and credit growth via lower borrowing rates. In fact, borrowing rates would have been higher in the absence of capital inflows as argued by Gochoco-Bautista and Canlas (2003). But capital inflows have been sterilized in the Philippines. This kept the borrowing rate higher than what would have been in the absence of intervention or from falling further in the absence of intervention. The Philippine case then provides a counter example wherein exchange rate intervention may not necessarily lead to lower interest rate given non-bond inflows. This is one argument which might have been overlooked by Blanchard et al. (2015).

\subsection{Sensitivity Tests}

Given the baseline results presented in Tables 1 to 3 , several sensitivity tests are conducted to address potential endogeneity and data considerations. First, given that there could be potential reverse causality between output or credit growth and capital inflows, it would be prudent to address potential endogeneity between these two parameters. One approach is to use lagged values of the regressors. The rationale for doing so is that lagged values of the regressors should not affect current output growth and credit change. Table 4 presents the results using lagged values of the regressors. The results are broadly consistent with the baseline results. However, other debt inflows and foreign reserves are now insignificant. Nonetheless, we still see the expansionary impact of total gross inflows, private bond inflows, and non-bond inflows, consistent in Tables 1 to 3.

Second, given that we used data on gross inflows from 1977 to 2015, several sensitivity tests are conducted addressing data considerations. First, knowing the expansionary impact of gross capital inflows on output and credit in the Philippines, there is merit to assess whether the same hold when we look at net capital inflows. Distinguishing between gross and net inflows is important in the literature as it takes into account the responses of foreign as well as domestic investors. Using gross inflows, the focus is on the impact of foreign-induced capital inflows in the Philippines, while net inflows consider both the actions of foreign and domestic investors. It would be important to assess whether net inflows themselves have expansionary or contractionary effect. Data on gross capital outflows from the Philippines are taken from the IMF's Balance of Payments Statistics, and net inflows are computed as liabilities minus assets following the Balance of Payments Manual 6. 
Table 5 presents the OLS results using net inflows. The estimates are similar to the baseline results using gross inflows. Total net inflows, bond net inflows, private bond net inflows, non-bond net inflows, and other debt net inflows have expansionary impact on output and credit growth. However, portfolio equity net inflows are now significant for credit change. In addition, U.S. GDP growth increases output growth and foreign reserves decreases credit change. These results are consistent with the baseline results for gross inflows. These findings indicate that capital inflows, whether gross or net, have expansionary effect on output and credit in the Philippines.

Another data consideration pertains to the treatment of unavailable data. In the IMF's Balance of Payments Statistics, some years have unavailable or have no data, specifically for portfolio equity inflows and public bond inflows. The OLS results presented in Tables 1 to 3 consider these cases as gross capital inflows having zero values. For instance, data on portfolio equity inflows started only in the early 1990's in line with stock market liberalization measures in the Philippines. As such, data in the 1970's to 1980's should be treated as zeros as there are no foreign capital inflows during that time. Furthermore, indicating zero values for gross inflows would lead to constant sample size of 39 observations in the OLS estimation. However, indicating zero values could potentially bias the results. This could explain why portfolio equity inflows have negative but insignificant values in Tables 1 to 3.

As sensitivity test, we ran the same estimation removing years when data is unavailable, instead of treating them as zeros. Table 6 presents the results when we remove the zeros from portfolio equity inflows and public bond inflows when data are unavailable. Again, the results are broadly consistent with baseline results in Tables 1 to 3; however portfolio equity inflows now have positive but still insignificant sign. But we note that foreign direct inflows have negative sign albeit insignificant. The estimates validate the baseline results such that total gross inflows, bond inflows, private bond inflows, non-bond inflows, and other debt inflows have expansionary impact on output and credit growth in the Philippines.

Since our sample period covers almost four decades of data, a lot of structural changes could have taken place. One would be the shift in monetary policy stance from monetary aggregate targeting to inflation targeting framework. Another would be the policy response to the exchange rate. In order to validate the expansionary impact of capital inflows to the Philippines, we split the sample into two periods. The first period includes 1977 to 1997 covering the years when the currency was managed or relatively fixed. The second period covers 1998 to 2015 when the currency was allowed to be more flexible and market-determined. This structural break corresponds to the Asian financial crisis of 1997-98.

Tables 7 and 8 present the results for output and credit growth, respectively, for the two sample periods. Here, we find interesting results. In Table 7, bond inflows are expansionary for output growth in period 1, while in Table 8 , it is contractionary in period 2. But the expansionary impact of bond inflows on output growth in period 1 is driven by private bond inflows while public bond inflows have negative signs. In period 2, the estimated coefficient is positive for private bond inflows and negative for public bond inflows. These results suggest two things. First, the expansionary impact of bond inflows is strong when the exchange rate is relatively managed or fixed. Second, the expansionary impact of bond inflows can be primarily due to private bond inflows while the contractionary impact can be attributed to public bond inflows. For credit growth in Table 8, bond inflows are expansionary in both periods. This is at odds with the theoretical model of Blanchard et al. (2015). 
Lastly, annual data limits the number of observations to 39. Using quarterly data would be one way to check whether the baseline results hold. Table 9 presents the quarterly results. ${ }^{11}$ The results show that private bond inflows and non-bond inflows, including other debt inflows, have expansionary impact on output and credit growth. Public bond inflows tend to have negative sign but insignificant, while foreign direct investments have positive but insignificant sign. Overall, using quarterly data yields consistent results as with the baseline results. It is important to note that the estimated parameters have consistent signs and significance across specifications, unlike in the baseline results.

In summary, the results point to several important considerations in explaining the expansionary or contractionary impact of capital inflows to emerging economies. In the Philippines, bond inflows have an expansionary impact on output and credit growth. Non-bond inflows still have an overall positive effect on output and credit growth despite small foreign direct investment inflows because capital inflows can be in the form of other debt or banking inflows. The Philippines case clearly demonstrates that there is a lot to be considered in explaining why the impact of capital inflows in the standard open economy models is at odds with policy experience of emerging economies. Using a country-case study for the Philippines provides counter example on why bond inflows can have expansionary impact.

\section{Concluding Remarks}

This paper sets out to address whether capital inflows to the Philippines are expansionary or contractionary in line with the model predictions of Blanchard et al. (2015). Using annual data on various types of gross capital inflows from 1977 to 2015, we find that total gross inflows to the Philippines are expansionary for output and credit growth, suggesting an overall positive effect of capital inflows. This result implicitly validates the procyclical nature of capital inflows in the Philippines. However, unlike the findings of Blanchard et al. (2015), we find that bond inflows to the Philippines are expansionary. Several possible explanations are provided. First, the link between capital inflows and currency appreciation is weak under a managed exchange rate regime. Second, the contractionary impact of bond inflows does not hold when the country has less developed capital markets or receives small bond inflows. Third, bond inflows might not necessary be contractionary if proceeds from debt issuance are channelled to productive investments.

But similar to Blanchard et al. (2015), non-bond inflows have an overall positive effect on output and credit growth despite relatively restricted foreign direct investment inflows. By focusing on the Philippines, we find that even a country which relies less on external demand and foreign direct investment, has less developed capital market, and engages in foreign exchange intervention still benefits from the expansionary effect of capital inflows. This leaves room to consider other channels through which capital inflows can have contractionary effect on output.

\footnotetext{
${ }^{11}$ Quarterly data capital flows data are taken from the International Financial Statistics of the International Monetary Fund. Quarterly data for control and policy variables are taken from Oxford Economics Database. Quarterly data start in 1981Q4 as the data on terms of trade are available only in 1980Q1.
} 
Figure 1: Gross and Net Capital Inflows to the Philippines

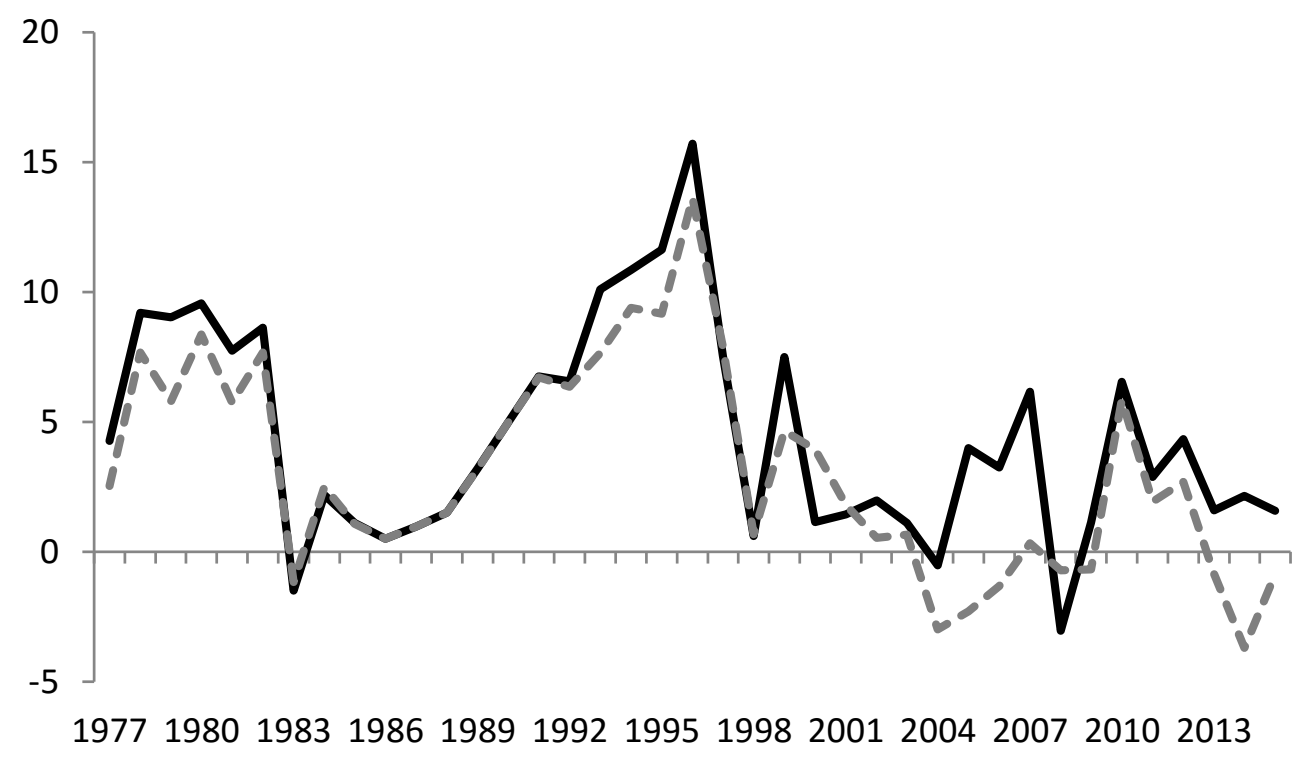

Notes: Gross and net inflows are in percent of nominal GDP. Data taken from the Balance of Payment Statistics of the International Monetary Fund.

Figure 2: Bond and Non-Bond Gross Inflows to the Philippines

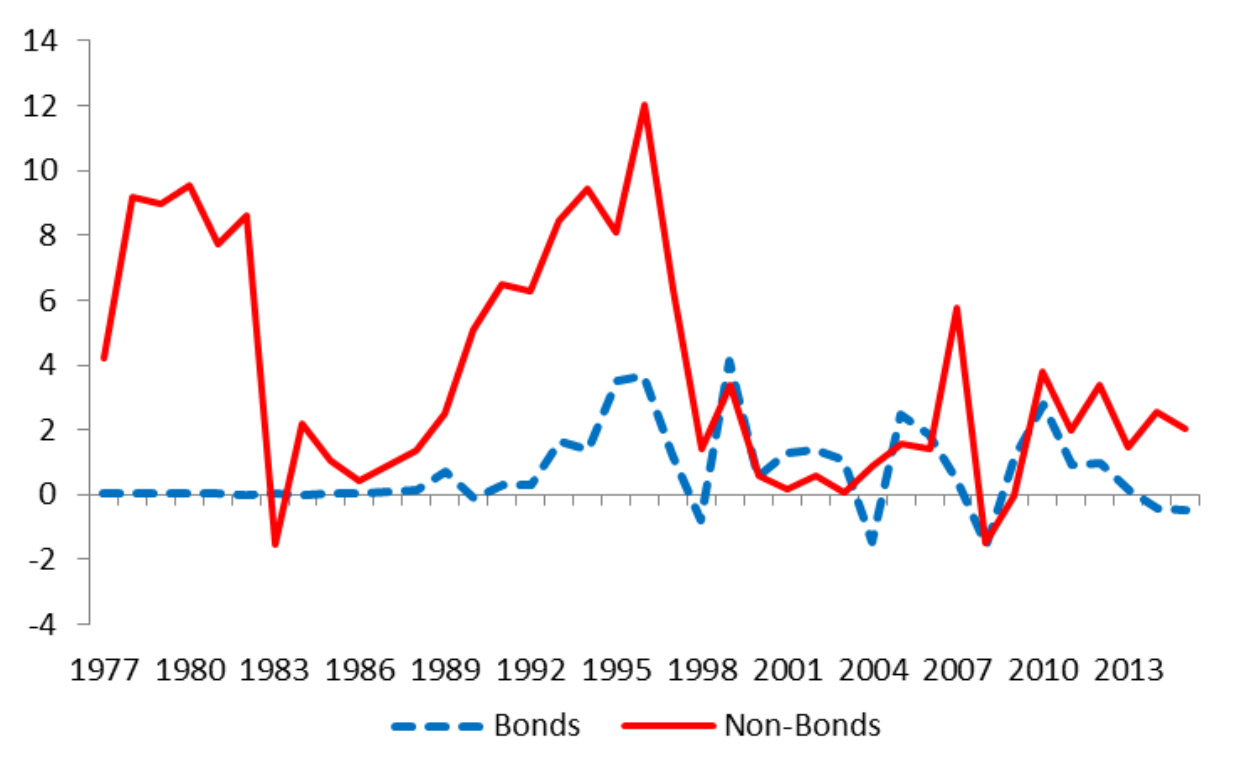

Notes: Bond inflows refer to portfolio debt gross inflows. Non-bond inflows refer to the sum of foreign direct investment, portfolio equity, and other debt gross inflows. Values are in percent of nominal GDP. Data taken from the Balance of Payment Statistics of the International Monetary Fund. 
Figure 3: Different Types of Gross Capital Inflows to the Philippines

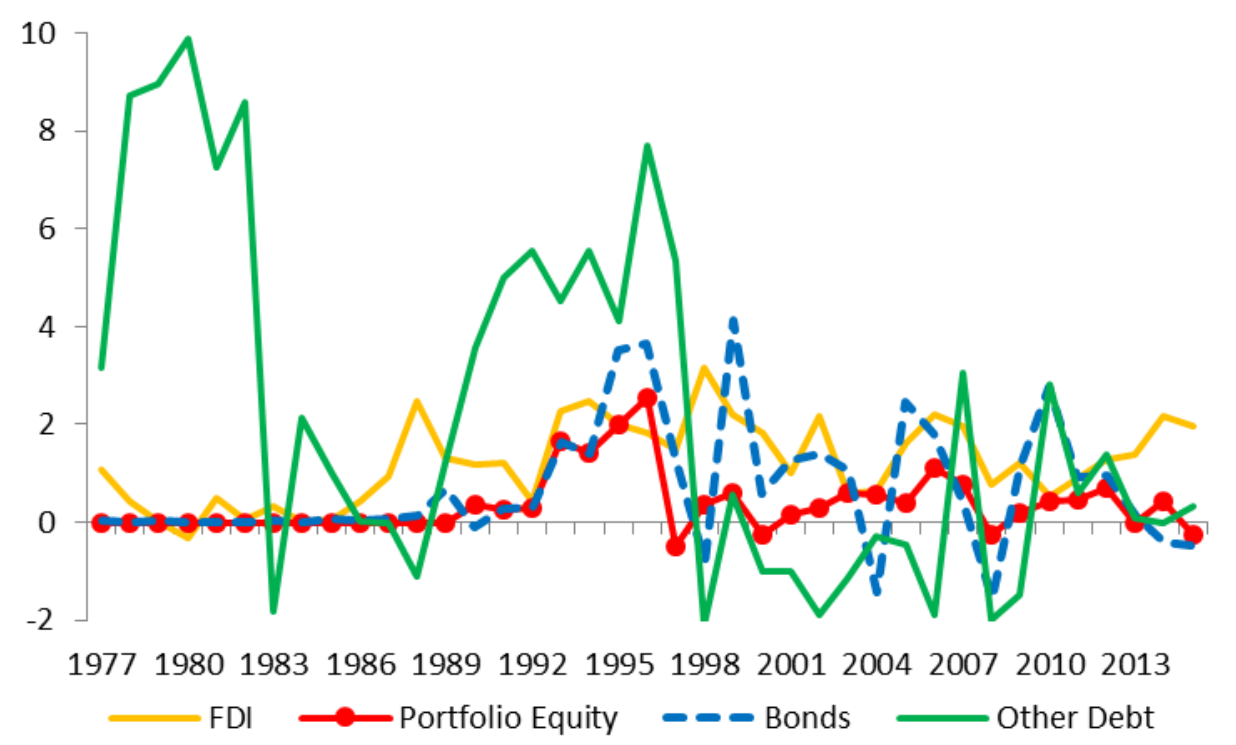

Notes: Bond inflows refer to portfolio debt gross inflows. Other debt inflows refer to other investment liabilities. Values are in percent of nominal GDP. Data taken from the Balance of Payment Statistics of the International Monetary Fund.

Figure 4: Gross Capital Inflows to the Philippines and Emerging East Asia

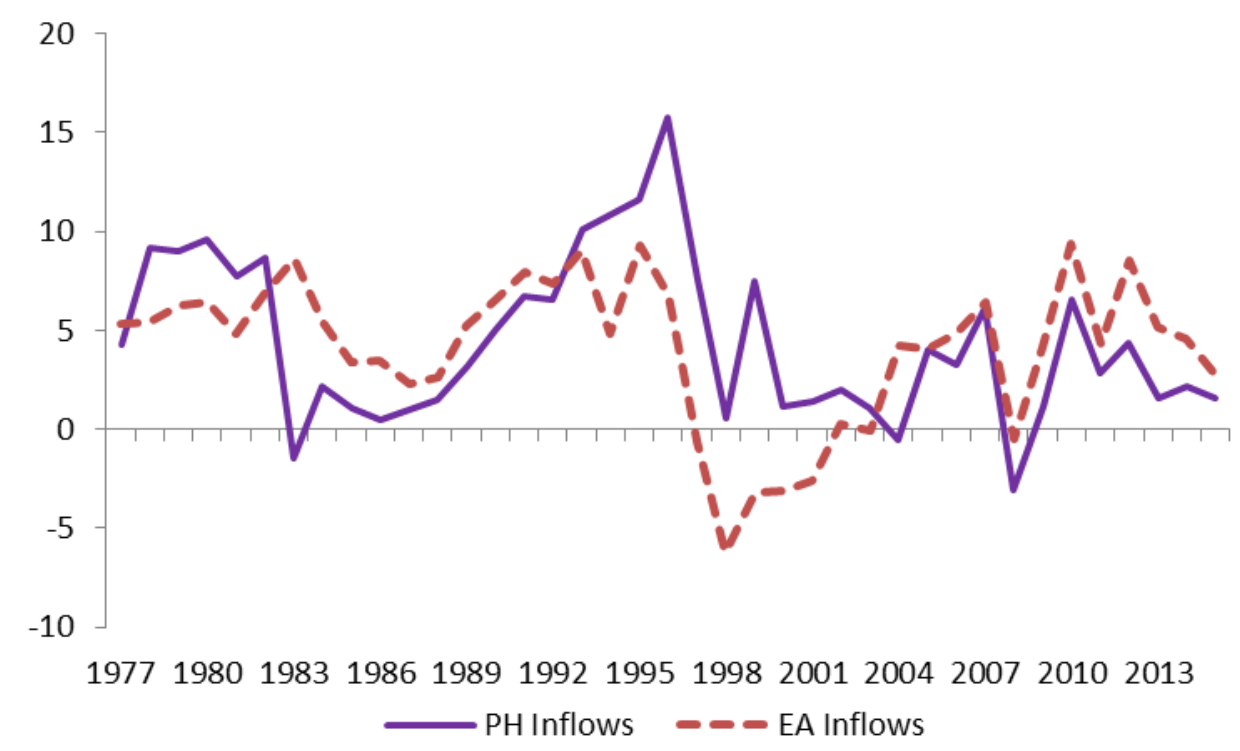

Notes: PH inflows refer to total gross capital inflows to the Philippines. EA inflows refer to the total gross capital inflows to Indonesia, Malaysia, and Thailand. Values are in percent of nominal GDP. Data taken from the Balance of Payment Statistics of the International Monetary Fund. 
Figure 5: Philippine Peso-US Dollar Exchange Rate

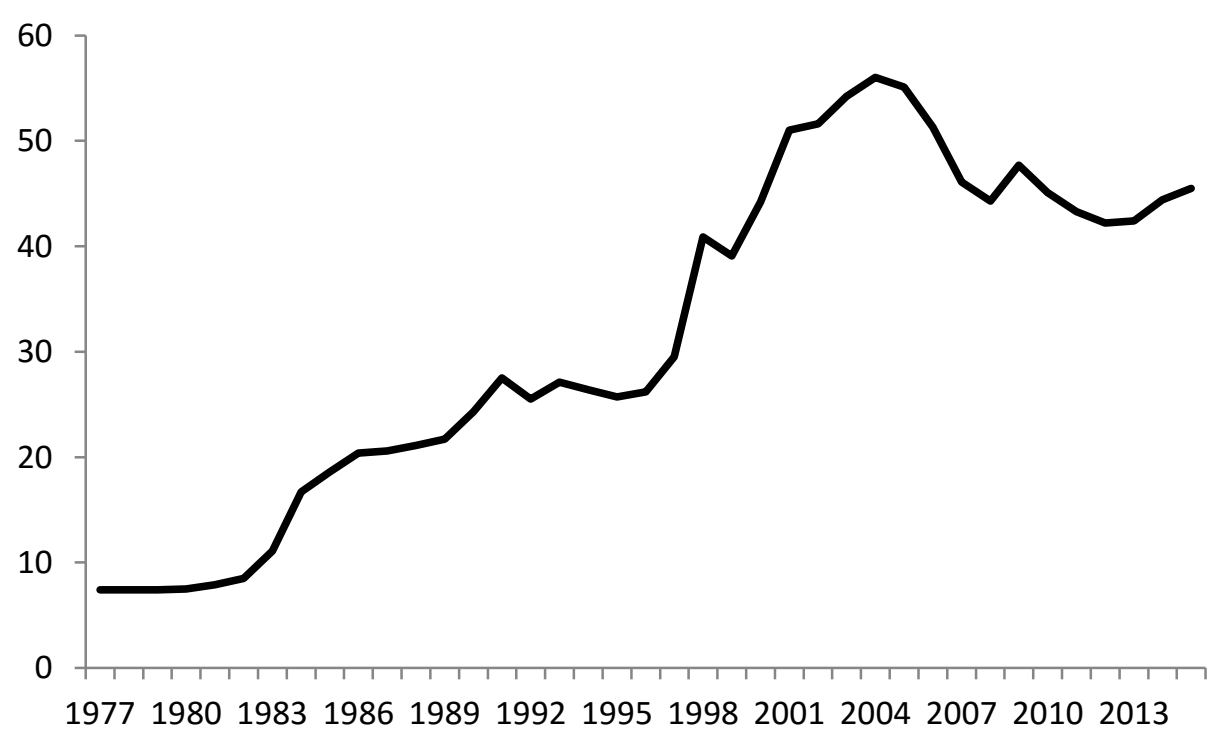

Notes: Data pertains to average annual exchange rate (PHP per USD). Data taken from International Financial Statistics of the International Monetary Fund.

Figure 6: Volatility of Philippine Peso-US Dollar Exchange Rate

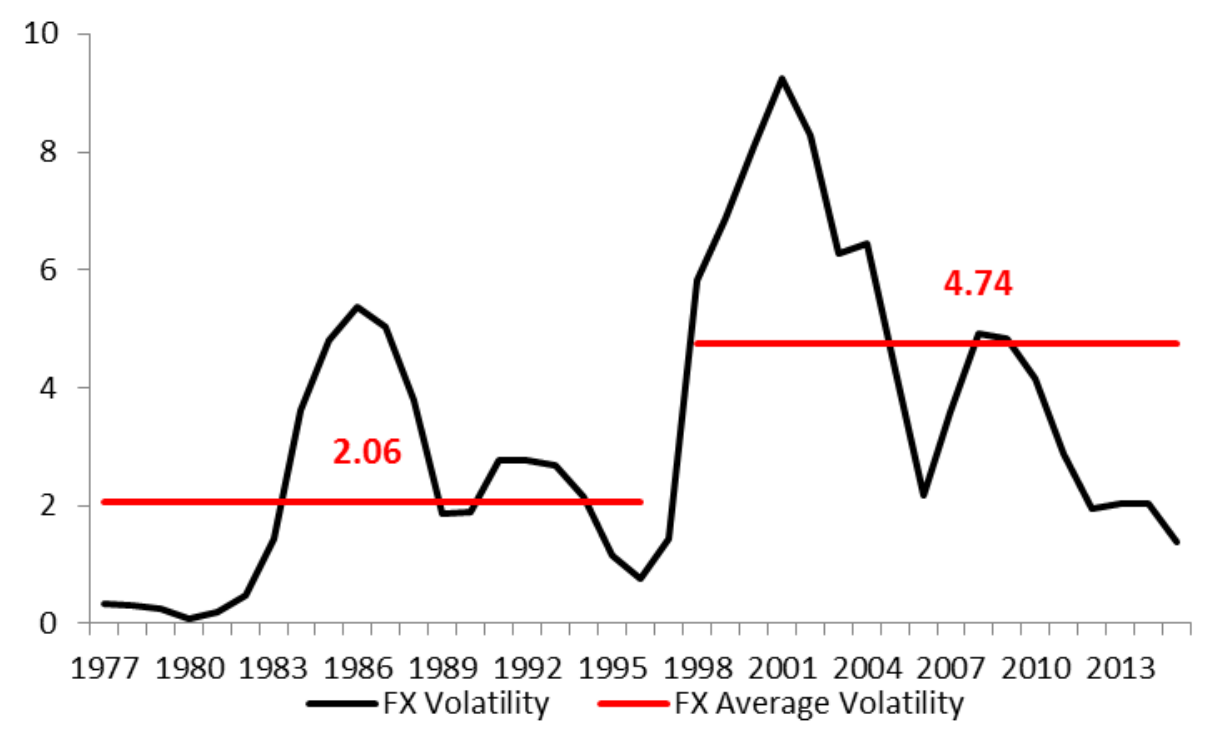

Note: Volatility refers to standard deviation of the exchange rate. Average annual exchange rate data taken from the International Financial Statistics of the International Monetary Fund. 
Table 1: OLS Estimation of Output and Credit Growth on Gross Capital Inflows

\begin{tabular}{|c|c|c|c|c|c|c|c|c|c|c|}
\hline VARIABLES & \multicolumn{5}{|c|}{ Output Growth } & \multicolumn{5}{|c|}{ Credit Growth } \\
\hline Inflows & $\begin{array}{l}0.266^{\star *} \\
(0.099)\end{array}$ & & & & & $\begin{array}{c}0.868^{\star \star *} \\
(0.276)\end{array}$ & & & & \\
\hline Bond Inflows & & $\begin{array}{c}0.137 \\
(0.260)\end{array}$ & & $\begin{array}{c}0.290 \\
(0.340)\end{array}$ & & & $\begin{array}{l}1.503^{\star *} \\
(0.612)\end{array}$ & & $\begin{array}{l}1.527^{\star} \\
(0.773)\end{array}$ & \\
\hline Private Bond Inflows & & & $\begin{array}{c}0.360 \\
(0.351)\end{array}$ & & $\begin{array}{l}1.002^{\star} \\
(0.566)\end{array}$ & & & $\begin{array}{c}3.406^{\star \star \star} \\
(1.158)\end{array}$ & & $\begin{array}{c}0.904 \\
(0.670)\end{array}$ \\
\hline Public Bond Inflows & & & $\begin{array}{l}-0.036 \\
(0.371)\end{array}$ & & $\begin{array}{c}0.024 \\
(0.383)\end{array}$ & & & $\begin{array}{l}-0.002 \\
(0.480)\end{array}$ & & $\begin{array}{c}0.034 \\
(0.420)\end{array}$ \\
\hline Non-Bond Inflows & & $\begin{array}{l}0.294^{\star *} \\
(0.113)\end{array}$ & $\begin{array}{l}0.252^{*} \\
(0.142)\end{array}$ & & & & $\begin{array}{l}0.723^{\star *} \\
(0.272)\end{array}$ & $\begin{array}{l}0.429^{\star} \\
(0.239)\end{array}$ & & \\
\hline FDI Inflows & & & & $\begin{array}{c}0.432 \\
(0.643)\end{array}$ & $\begin{array}{c}0.423 \\
(0.631)\end{array}$ & & & & $\begin{array}{c}0.246 \\
(1.315)\end{array}$ & $\begin{array}{c}0.682 \\
(0.682)\end{array}$ \\
\hline Portfolio Equity Inflows & & & & $\begin{array}{l}-0.352 \\
(0.587)\end{array}$ & $\begin{array}{l}-1.098 \\
(0.968)\end{array}$ & & & & $\begin{array}{c}0.954 \\
(1.291)\end{array}$ & $\begin{array}{l}-1.318 \\
(1.094)\end{array}$ \\
\hline Other Debt Inflows & & & & $\begin{array}{l}0.338^{\star \star} \\
(0.126)\end{array}$ & $\begin{array}{l}0.277^{*} \\
(0.141)\end{array}$ & & & & $\begin{array}{l}0.697^{\star *} \\
(0.288)\end{array}$ & $\begin{array}{l}0.326^{\star \star} \\
(0.129)\end{array}$ \\
\hline Lag Dependent Variable & $\begin{array}{c}0.287 \\
(0.221)\end{array}$ & $\begin{array}{c}0.277 \\
(0.233)\end{array}$ & $\begin{array}{c}0.278 \\
(0.232)\end{array}$ & $\begin{array}{c}0.264 \\
(0.229)\end{array}$ & $\begin{array}{c}0.256 \\
(0.223)\end{array}$ & $\begin{array}{c}0.093 \\
(0.194)\end{array}$ & $\begin{array}{c}0.117 \\
(0.192)\end{array}$ & $\begin{array}{c}0.006 \\
(0.155)\end{array}$ & $\begin{array}{c}0.133 \\
(0.168)\end{array}$ & $\begin{array}{c}0.073 \\
(0.119)\end{array}$ \\
\hline US GDP Growth & $\begin{array}{l}0.397^{\star *} \\
(0.161)\end{array}$ & $\begin{array}{l}0.414^{\star \star} \\
(0.167)\end{array}$ & $\begin{array}{l}0.416^{\star \star} \\
(0.178)\end{array}$ & $\begin{array}{l}0.424^{* *} \\
(0.186)\end{array}$ & $\begin{array}{l}0.441^{\star \star} \\
(0.210)\end{array}$ & $\begin{array}{l}-0.206 \\
(0.425)\end{array}$ & $\begin{array}{l}-0.288 \\
(0.376)\end{array}$ & $\begin{array}{l}-0.248 \\
(0.306)\end{array}$ & $\begin{array}{l}-0.251 \\
(0.387)\end{array}$ & $\begin{array}{l}0.459^{\star \star} \\
(0.196)\end{array}$ \\
\hline Change in Terms of Trade & $\begin{array}{l}-0.023 \\
(0.043)\end{array}$ & $\begin{array}{l}-0.020 \\
(0.044)\end{array}$ & $\begin{array}{l}-0.019 \\
(0.044)\end{array}$ & $\begin{array}{l}-0.023 \\
(0.041)\end{array}$ & $\begin{array}{l}-0.023 \\
(0.041)\end{array}$ & $\begin{array}{l}-0.008 \\
(0.086)\end{array}$ & $\begin{array}{l}-0.026 \\
(0.090)\end{array}$ & $\begin{array}{l}-0.029 \\
(0.078)\end{array}$ & $\begin{array}{l}-0.020 \\
(0.087)\end{array}$ & $\begin{array}{l}-0.052 \\
(0.047)\end{array}$ \\
\hline Policy Rate & $\begin{array}{c}-0.458^{\star \star \star} \\
(0.114)\end{array}$ & $\begin{array}{c}-0.470^{\star \star * *} \\
(0.123)\end{array}$ & $\begin{array}{c}-0.469^{\star \star \star} \\
(0.124)\end{array}$ & $\begin{array}{c}-0.480^{* \star *} \\
(0.128)\end{array}$ & $\begin{array}{c}-0.491^{* \star *} \\
(0.128)\end{array}$ & $\begin{array}{l}-0.396^{* *} \\
(0.162)\end{array}$ & $\begin{array}{l}-0.354^{* \star} \\
(0.164)\end{array}$ & $\begin{array}{c}-0.362^{\star *} \\
(0.159)\end{array}$ & $\begin{array}{l}-0.373^{\star} \\
(0.187)\end{array}$ & $\begin{array}{c}-0.562^{* \star *} \\
(0.110)\end{array}$ \\
\hline Foreign Reserves & $\begin{array}{l}-0.068 \\
(0.168)\end{array}$ & $\begin{array}{l}-0.060 \\
(0.171)\end{array}$ & $\begin{array}{l}-0.024 \\
(0.188)\end{array}$ & $\begin{array}{l}-0.058 \\
(0.166)\end{array}$ & $\begin{array}{c}0.032 \\
(0.195)\end{array}$ & $\begin{array}{l}-0.985^{\star *} \\
(0.367)\end{array}$ & $\begin{array}{c}-1.029^{\star * *} \\
(0.361)\end{array}$ & $\begin{array}{c}-0.780^{\star \star \star} \\
(0.276)\end{array}$ & $\begin{array}{c}-1.030^{\star * *} \\
(0.364)\end{array}$ & $\begin{array}{l}-0.015 \\
(0.182)\end{array}$ \\
\hline Constant & $\begin{array}{l}5.413^{\star \star \star} \\
(1.745)\end{array}$ & $\begin{array}{c}5.501^{\star \star *} \\
(1.845)\end{array}$ & $\begin{array}{c}5.593^{\star \star \star *} \\
(1.880)\end{array}$ & $\begin{array}{l}5.495^{\star \star} \\
(2.042)\end{array}$ & $\begin{array}{c}5.756^{\star \star *} \\
(2.024)\end{array}$ & $\begin{array}{l}3.213^{\star} \\
(1.737)\end{array}$ & $\begin{array}{l}3.118^{*} \\
(1.723)\end{array}$ & $\begin{array}{l}3.873^{\star \star} \\
(1.587)\end{array}$ & $\begin{array}{l}3.767 \\
(2.519)\end{array}$ & $\begin{array}{c}7.142^{\star \star \star} \\
(1.235)\end{array}$ \\
\hline $\begin{array}{l}\text { Observations } \\
\text { R-squared }\end{array}$ & $\begin{array}{c}39 \\
0.638 \\
\end{array}$ & $\begin{array}{c}39 \\
0.640\end{array}$ & $\begin{array}{c}39 \\
0.645 \\
\end{array}$ & $\begin{array}{c}39 \\
0.648 \\
\end{array}$ & $\begin{array}{c}39 \\
0.667 \\
\end{array}$ & $\begin{array}{c}39 \\
0.509 \\
\end{array}$ & $\begin{array}{c}39 \\
0.530 \\
\end{array}$ & $\begin{array}{c}39 \\
0.648 \\
\end{array}$ & $\begin{array}{c}39 \\
0.533 \\
\end{array}$ & $\begin{array}{c}39 \\
0.634 \\
\end{array}$ \\
\hline
\end{tabular}

Notes: Dependent variables are output and credit growth. Output growth refers to the year-on-year change of real GDP. Credit growth refers to the difference between current year and previous year domestic credit provided by the banking sector. Capital inflows and foreign reserves are expressed in percent of GDP. Private bond inflows include those from other sectors. Public bond inflows include general government and monetary authority. Other debt inflows refer to other investment liabilities in the Balance of Payments. Robust standard errors in are parentheses. ${ }^{* * *} p<0.01,{ }^{* *} p<0.05, * p<0.1$. 
Table 2: OLS Estimation of Tradable and Non-Tradable Sector Growth on Gross Capital Inflows

\begin{tabular}{|c|c|c|c|c|c|c|c|c|c|c|}
\hline \multirow[b]{2}{*}{ VARIABLES } & (1) & (2) & (3) & (4) & (5) & (6) & (7) & (8) & (9) & (10) \\
\hline & \multicolumn{5}{|c|}{ Tradable Sector Growth } & \multicolumn{5}{|c|}{ Non-Tradable Sector Growth } \\
\hline Inflows & $\begin{array}{l}0.275^{\star \star} \\
(0.117)\end{array}$ & & & & & $\begin{array}{l}0.279^{\star \star} \\
(0.110)\end{array}$ & & & & \\
\hline Bond Inflows & & $\begin{array}{c}0.240 \\
(0.295)\end{array}$ & & $\begin{array}{c}0.521 \\
(0.397)\end{array}$ & & & $\begin{array}{c}0.054 \\
(0.286)\end{array}$ & & $\begin{array}{c}0.144 \\
(0.367)\end{array}$ & \\
\hline Private Bond Inflows & & & $\begin{array}{c}0.349 \\
(0.437)\end{array}$ & & $\begin{array}{l}1.244^{*} \\
(0.713)\end{array}$ & & & $\begin{array}{c}0.335 \\
(0.382)\end{array}$ & & $\begin{array}{c}0.854 \\
(0.602)\end{array}$ \\
\hline Public Bond Inflows & & & $\begin{array}{c}0.152 \\
(0.389)\end{array}$ & & $\begin{array}{c}0.236 \\
(0.418)\end{array}$ & & & $\begin{array}{l}-0.161 \\
(0.403)\end{array}$ & & $\begin{array}{l}-0.118 \\
(0.418)\end{array}$ \\
\hline Non-Bond Inflows & & $\begin{array}{l}0.283^{\star \star} \\
(0.135)\end{array}$ & $\begin{array}{l}0.263^{*} \\
(0.153)\end{array}$ & & & & $\begin{array}{l}0.328^{\star \star} \\
(0.131)\end{array}$ & $\begin{array}{c}0.274 \\
(0.170)\end{array}$ & & \\
\hline FDI Inflows & & & & $\begin{array}{c}0.323 \\
(0.675)\end{array}$ & $\begin{array}{c}0.355 \\
(0.650)\end{array}$ & & & & $\begin{array}{c}0.574 \\
(0.746)\end{array}$ & $\begin{array}{c}0.548 \\
(0.741)\end{array}$ \\
\hline Portfolio Equity Inflows & & & & $\begin{array}{l}-0.748 \\
(0.535)\end{array}$ & $\begin{array}{l}-1.530 \\
(1.048)\end{array}$ & & & & $\begin{array}{l}-0.164 \\
(0.743)\end{array}$ & $\begin{array}{l}-0.896 \\
(1.083)\end{array}$ \\
\hline Other Debt Inflows & & & & $\begin{array}{l}0.348^{\star \star} \\
(0.138)\end{array}$ & $\begin{array}{l}0.294^{*} \\
(0.150)\end{array}$ & & & & $\begin{array}{l}0.363^{\star \star} \\
(0.153)\end{array}$ & $\begin{array}{l}0.299^{*} \\
(0.175)\end{array}$ \\
\hline Lag Dependent Variable & $\begin{array}{c}0.262 \\
(0.177)\end{array}$ & $\begin{array}{c}0.259 \\
(0.189)\end{array}$ & $\begin{array}{c}0.255 \\
(0.192)\end{array}$ & $\begin{array}{c}0.257 \\
(0.167)\end{array}$ & $\begin{array}{c}0.227 \\
(0.165)\end{array}$ & $\begin{array}{c}0.247 \\
(0.238)\end{array}$ & $\begin{array}{c}0.236 \\
(0.246)\end{array}$ & $\begin{array}{c}0.242 \\
(0.245)\end{array}$ & $\begin{array}{c}0.220 \\
(0.245)\end{array}$ & $\begin{array}{c}0.224 \\
(0.239)\end{array}$ \\
\hline US GDP Growth & $\begin{array}{l}0.616^{\star \star} \\
(0.285)\end{array}$ & $\begin{array}{l}0.621^{*} \\
(0.308)\end{array}$ & $\begin{array}{l}0.623^{*} \\
(0.314)\end{array}$ & $\begin{array}{l}0.650^{*} \\
(0.324)\end{array}$ & $\begin{array}{l}0.670^{*} \\
(0.338)\end{array}$ & $\begin{array}{l}0.277^{\star} \\
(0.161)\end{array}$ & $\begin{array}{l}0.306^{*} \\
(0.164)\end{array}$ & $\begin{array}{l}0.307^{*} \\
(0.178)\end{array}$ & $\begin{array}{c}0.300 \\
(0.191)\end{array}$ & $\begin{array}{c}0.316 \\
(0.218)\end{array}$ \\
\hline Change in Terms of Trade & $\begin{array}{l}-0.008 \\
(0.054)\end{array}$ & $\begin{array}{l}-0.008 \\
(0.054)\end{array}$ & $\begin{array}{l}-0.008 \\
(0.055)\end{array}$ & $\begin{array}{l}-0.008 \\
(0.050)\end{array}$ & $\begin{array}{l}-0.010 \\
(0.050)\end{array}$ & $\begin{array}{l}-0.043 \\
(0.044)\end{array}$ & $\begin{array}{l}-0.037 \\
(0.046)\end{array}$ & $\begin{array}{l}-0.036 \\
(0.045)\end{array}$ & $\begin{array}{l}-0.042 \\
(0.045)\end{array}$ & $\begin{array}{l}-0.040 \\
(0.044)\end{array}$ \\
\hline Policy Rate & $\begin{array}{c}-0.457^{\star \star \star} \\
(0.115)\end{array}$ & $\begin{array}{c}-0.461^{\star \star \star} \\
(0.124)\end{array}$ & $\begin{array}{c}-0.462^{\star \star \star} \\
(0.125)\end{array}$ & $\begin{array}{c}-0.481^{\star \star \star} \\
(0.130)\end{array}$ & $\begin{array}{c}-0.499^{* \star *} \\
(0.130)\end{array}$ & $\begin{array}{c}-0.478^{\star \star \star} \\
(0.129)\end{array}$ & $\begin{array}{c}-0.496^{\star \star \star} \\
(0.139)\end{array}$ & $\begin{array}{c}-0.494^{\star \star \star} \\
(0.142)\end{array}$ & $\begin{array}{c}-0.498^{\star \star *} \\
(0.142)\end{array}$ & $\begin{array}{c}-0.506^{\star * \star} \\
(0.144)\end{array}$ \\
\hline Foreign Reserves & $\begin{array}{l}-0.009 \\
(0.175)\end{array}$ & $\begin{array}{l}-0.008 \\
(0.177)\end{array}$ & $\begin{array}{c}0.008 \\
(0.182)\end{array}$ & $\begin{array}{l}-0.003 \\
(0.163)\end{array}$ & $\begin{array}{c}0.082 \\
(0.177)\end{array}$ & $\begin{array}{l}-0.136 \\
(0.195)\end{array}$ & $\begin{array}{l}-0.119 \\
(0.197)\end{array}$ & $\begin{array}{l}-0.073 \\
(0.224)\end{array}$ & $\begin{array}{l}-0.117 \\
(0.199)\end{array}$ & $\begin{array}{l}-0.024 \\
(0.239)\end{array}$ \\
\hline Constant & $\begin{array}{l}4.193^{\star \star \star} \\
(1.488)\end{array}$ & $\begin{array}{l}4.222^{\star \star \star} \\
(1.515)\end{array}$ & $\begin{array}{l}4.292^{\star *} \\
(1.581)\end{array}$ & $\begin{array}{l}4.344^{\star \star} \\
(1.787)\end{array}$ & $\begin{array}{l}4.695^{\star *} \\
(1.797)\end{array}$ & $\begin{array}{l}6.510^{\star \star \star} \\
(1.988)\end{array}$ & $\begin{array}{l}6.624^{* \star *} \\
(2.072)\end{array}$ & $\begin{array}{l}6.708^{\star \star \star} \\
(2.107)\end{array}$ & $\begin{array}{l}6.457^{\star \star \star} \\
(2.301)\end{array}$ & $\begin{array}{l}6.663^{\star \star \star} \\
(2.299)\end{array}$ \\
\hline $\begin{array}{l}\text { Observations } \\
\text { R-squared }\end{array}$ & $\begin{array}{c}39 \\
0.603\end{array}$ & $\begin{array}{c}39 \\
0.603\end{array}$ & $\begin{array}{c}39 \\
0.605\end{array}$ & $\begin{array}{c}39 \\
0.626\end{array}$ & $\begin{array}{c}39 \\
0.646\end{array}$ & $\begin{array}{c}39 \\
0.570\end{array}$ & $\begin{array}{c}39 \\
0.576\end{array}$ & $\begin{array}{c}39 \\
0.581\end{array}$ & $\begin{array}{c}39 \\
0.580\end{array}$ & $\begin{array}{c}39 \\
0.595\end{array}$ \\
\hline
\end{tabular}

Notes: Dependent variables are tradable and non-tradable sector growth. Tradable sector includes agriculture and manufacturing. Nontradable sector includes industry minus manufacturing and services. Growth refers to the year-on-year change of real GDP by sector. Capital inflows and foreign reserves are expressed in percent of GDP. Private bond inflows include those from other sectors. Public bond inflows include general government and monetary authority. Other debt inflows refer to other investment liabilities in the Balance of Payments. Robust standard errors in are parentheses. ${ }^{* *} p<0.01, * * p<0.05, * p<0.1$. 
Table 3: OLS Estimation of Public and Private Sector Credit Growth on Gross Capital Inflows

\begin{tabular}{|c|c|c|c|c|c|c|c|c|c|c|}
\hline \multirow[b]{2}{*}{ VARIABLES } & (1) & (2) & (3) & (4) & (5) & (6) & (7) & (8) & (9) & (10) \\
\hline & \multicolumn{5}{|c|}{ Public Sector Credit Growth } & \multicolumn{5}{|c|}{ Private Sector Credit Growth } \\
\hline Inflows & $\begin{array}{c}0.059 \\
(0.048)\end{array}$ & & & & & $\begin{array}{c}0.789^{\star \star \star} \\
(0.240)\end{array}$ & & & & \\
\hline Bond Inflows & & $\begin{array}{c}0.205 \\
(0.173)\end{array}$ & & $\begin{array}{c}0.205 \\
(0.250)\end{array}$ & & & $\begin{array}{l}1.228^{\star *} \\
(0.499)\end{array}$ & & $\begin{array}{l}1.185^{\star} \\
(0.656)\end{array}$ & \\
\hline Private Bond Inflows & & & $\begin{array}{l}0.480^{*} \\
(0.279)\end{array}$ & & $\begin{array}{l}0.739^{\star} \\
(0.364)\end{array}$ & & & $\begin{array}{c}3.018^{\star \star \star} \\
(0.862)\end{array}$ & & $\begin{array}{c}4.195^{\star \star \star} \\
(0.901)\end{array}$ \\
\hline Public Bond Inflows & & & $\begin{array}{l}-0.008 \\
(0.283)\end{array}$ & & $\begin{array}{c}0.005 \\
(0.290)\end{array}$ & & & $\begin{array}{l}-0.258 \\
(0.434)\end{array}$ & & $\begin{array}{l}-0.092 \\
(0.395)\end{array}$ \\
\hline Non-Bond Inflows & & $\begin{array}{c}0.029 \\
(0.055)\end{array}$ & $\begin{array}{l}-0.022 \\
(0.050)\end{array}$ & & & & $\begin{array}{c}0.681^{\star \star \star} \\
(0.246)\end{array}$ & $\begin{array}{l}0.419^{* *} \\
(0.204)\end{array}$ & & \\
\hline FDI Inflows & & & & $\begin{array}{c}0.223 \\
(0.316)\end{array}$ & $\begin{array}{c}0.207 \\
(0.272)\end{array}$ & & & & $\begin{array}{c}0.093 \\
(1.132)\end{array}$ & $\begin{array}{c}0.294 \\
(0.814)\end{array}$ \\
\hline Portfolio Equity Inflows & & & & $\begin{array}{l}-0.101 \\
(0.463)\end{array}$ & $\begin{array}{l}-0.657 \\
(0.446)\end{array}$ & & & & $\begin{array}{c}1.237 \\
(1.099)\end{array}$ & $\begin{array}{l}-1.832 \\
(1.099)\end{array}$ \\
\hline Other Debt Inflows & & & & $\begin{array}{c}0.038 \\
(0.049)\end{array}$ & $\begin{array}{l}-0.009 \\
(0.050)\end{array}$ & & & & $\begin{array}{l}0.631^{\star *} \\
(0.262)\end{array}$ & $\begin{array}{l}0.437^{\star \star} \\
(0.209)\end{array}$ \\
\hline Lag Dependent Variable & $\begin{array}{c}0.045 \\
(0.169)\end{array}$ & $\begin{array}{c}0.008 \\
(0.161)\end{array}$ & $\begin{array}{c}0.007 \\
(0.170)\end{array}$ & $\begin{array}{c}0.008 \\
(0.170)\end{array}$ & $\begin{array}{c}0.016 \\
(0.164)\end{array}$ & $\begin{array}{c}0.097 \\
(0.184)\end{array}$ & $\begin{array}{c}0.129 \\
(0.185)\end{array}$ & $\begin{array}{l}-0.002 \\
(0.141)\end{array}$ & $\begin{array}{c}0.149 \\
(0.158)\end{array}$ & $\begin{array}{c}0.011 \\
(0.117)\end{array}$ \\
\hline US GDP Growth & $\begin{array}{l}-0.085 \\
(0.088)\end{array}$ & $\begin{array}{l}-0.101 \\
(0.083)\end{array}$ & $\begin{array}{l}-0.099 \\
(0.083)\end{array}$ & $\begin{array}{l}-0.117 \\
(0.091)\end{array}$ & $\begin{array}{l}-0.104 \\
(0.091)\end{array}$ & $\begin{array}{l}-0.086 \\
(0.366)\end{array}$ & $\begin{array}{l}-0.142 \\
(0.329)\end{array}$ & $\begin{array}{l}-0.107 \\
(0.250)\end{array}$ & $\begin{array}{l}-0.105 \\
(0.342)\end{array}$ & $\begin{array}{l}-0.035 \\
(0.236)\end{array}$ \\
\hline Change in Terms of Trade & $\begin{array}{c}0.004 \\
(0.022)\end{array}$ & $\begin{array}{l}-0.000 \\
(0.024)\end{array}$ & $\begin{array}{c}0.000 \\
(0.022)\end{array}$ & $\begin{array}{l}-0.002 \\
(0.025)\end{array}$ & $\begin{array}{l}-0.001 \\
(0.023)\end{array}$ & $\begin{array}{l}-0.032 \\
(0.068)\end{array}$ & $\begin{array}{l}-0.043 \\
(0.071)\end{array}$ & $\begin{array}{l}-0.045 \\
(0.057)\end{array}$ & $\begin{array}{l}-0.037 \\
(0.068)\end{array}$ & $\begin{array}{l}-0.042 \\
(0.051)\end{array}$ \\
\hline Policy Rate & $\begin{array}{l}0.014 \\
(0.046)\end{array}$ & $\begin{array}{c}0.025 \\
(0.045)\end{array}$ & $\begin{array}{c}0.025 \\
(0.044)\end{array}$ & $\begin{array}{l}0.033 \\
(0.049)\end{array}$ & $\begin{array}{c}0.025 \\
(0.046)\end{array}$ & $\begin{array}{c}-0.420^{\star \star \star} \\
(0.139)\end{array}$ & $\begin{array}{c}-0.389^{* *} \\
(0.144)\end{array}$ & $\begin{array}{c}-0.405^{\star \star \star *} \\
(0.137)\end{array}$ & $\begin{array}{c}-0.406^{\star *} \\
(0.165)\end{array}$ & $\begin{array}{c}-0.449^{\star \star \star} \\
(0.127)\end{array}$ \\
\hline Foreign Reserves & $\begin{array}{c}-0.196^{\star \star \star} \\
(0.066)\end{array}$ & $\begin{array}{c}-0.213^{\star \star \star *} \\
(0.068)\end{array}$ & $\begin{array}{l}-0.169^{* *} \\
(0.077)\end{array}$ & $\begin{array}{c}-0.209^{\star \star \star *} \\
(0.076)\end{array}$ & $\begin{array}{l}-0.139^{\star} \\
(0.078)\end{array}$ & $\begin{array}{l}-0.831^{* *} \\
(0.309)\end{array}$ & $\begin{array}{c}-0.857^{\star \star *} \\
(0.304)\end{array}$ & $\begin{array}{l}-0.613^{\star *} \\
(0.223)\end{array}$ & $\begin{array}{c}-0.861^{* * *} \\
(0.307)\end{array}$ & $\begin{array}{c}-0.506^{* *} \\
(0.226)\end{array}$ \\
\hline Constant & $\begin{array}{l}0.314 \\
(0.531)\end{array}$ & $\begin{array}{c}0.275 \\
(0.526)\end{array}$ & $\begin{array}{l}0.396 \\
(0.506)\end{array}$ & $\begin{array}{l}0.017 \\
(0.701)\end{array}$ & $\begin{array}{c}0.189 \\
(0.648)\end{array}$ & $\begin{array}{l}3.066^{\star \star} \\
(1.453)\end{array}$ & $\begin{array}{l}2.999^{\star} \\
(1.479)\end{array}$ & $\begin{array}{l}3.767^{\star \star \star} \\
(1.329)\end{array}$ & $\begin{array}{l}3.745^{\star} \\
(2.203)\end{array}$ & $\begin{array}{c}4.383^{\star \star *} \\
(1.437)\end{array}$ \\
\hline $\begin{array}{l}\text { Observations } \\
\text { R-squared }\end{array}$ & $\begin{array}{c}39 \\
0.171\end{array}$ & $\begin{array}{c}39 \\
0.189\end{array}$ & $\begin{array}{c}39 \\
0.235\end{array}$ & $\begin{array}{c}39 \\
0.200\end{array}$ & $\begin{array}{c}39 \\
0.273\end{array}$ & $\begin{array}{c}39 \\
0.561\end{array}$ & $\begin{array}{c}39 \\
0.573\end{array}$ & $\begin{array}{c}39 \\
0.714\end{array}$ & $\begin{array}{c}39 \\
0.580\end{array}$ & $\begin{array}{c}39 \\
0.752\end{array}$ \\
\hline
\end{tabular}

Notes: Dependent variables are public and private sector credit growth. Public sector credit includes those to general government and monetary authority. Private sector credit includes those from other depository corporation, financial corporation, non-financial corporations, and households. Capital inflows and foreign reserves are expressed in percent of GDP. Private bond inflows include those from other sectors. Public bond inflows include general government and monetary authority. Other debt inflows refer to other investment liabilities in the Balance of Payments. Robust standard errors in are parentheses. ${ }^{* * *} p<0.01,{ }^{* *} p<0.05,{ }^{*} p<0.1$. 
Table 4: OLS Estimation of Output and Credit Growth on Using Lagged Capital Inflows

\begin{tabular}{|c|c|c|c|c|c|c|c|c|c|c|}
\hline \multirow[b]{2}{*}{ VARIABLES } & (1) & (2) & (3) & (4) & (5) & (6) & (7) & (8) & (9) & (10) \\
\hline & \multicolumn{5}{|c|}{ Output Growth } & \multicolumn{5}{|c|}{ Credit Growth } \\
\hline Inflows & $\begin{array}{l}0.206^{*} \\
(0.101)\end{array}$ & & & & & $\begin{array}{c}0.610^{* \star *} \\
(0.198)\end{array}$ & & & & \\
\hline Bond Inflows & & $\begin{array}{c}0.197 \\
(0.207)\end{array}$ & & $\begin{array}{c}0.039 \\
(0.382)\end{array}$ & & & $\begin{array}{c}0.487 \\
(0.557)\end{array}$ & & $\begin{array}{l}-0.505 \\
(0.694)\end{array}$ & \\
\hline Private Bond Inflows & & & $\begin{array}{c}0.258 \\
(0.252)\end{array}$ & & $\begin{array}{l}-0.099 \\
(0.770)\end{array}$ & & & $\begin{array}{l}2.372^{*} \\
(1.271)\end{array}$ & & $\begin{array}{c}-0.576 \\
(1.188)\end{array}$ \\
\hline Public Bond Inflows & & & $\begin{array}{c}0.161 \\
(0.347)\end{array}$ & & $\begin{array}{c}0.080 \\
(0.422)\end{array}$ & & & $\begin{array}{l}-0.336 \\
(0.487)\end{array}$ & & $\begin{array}{c}0.073 \\
(0.346)\end{array}$ \\
\hline Non-Bond Inflows & & $\begin{array}{l}0.208^{*} \\
(0.119)\end{array}$ & $\begin{array}{c}0.199 \\
(0.132)\end{array}$ & & & & $\begin{array}{c}0.635^{\star \star *} \\
(0.214)\end{array}$ & $\begin{array}{l}0.452^{* *} \\
(0.207)\end{array}$ & & \\
\hline FDI Inflows & & & & $\begin{array}{c}0.235 \\
(0.699)\end{array}$ & $\begin{array}{c}0.222 \\
(0.745)\end{array}$ & & & & $\begin{array}{c}0.608 \\
(1.239)\end{array}$ & $\begin{array}{c}0.505 \\
(0.744)\end{array}$ \\
\hline Portfolio Equity Inflows & & & & $\begin{array}{c}0.759 \\
(0.944)\end{array}$ & $\begin{array}{c}0.892 \\
(1.402)\end{array}$ & & & & $\begin{array}{c}4.363 \\
(3.001)\end{array}$ & $\begin{array}{c}1.021 \\
(1.462)\end{array}$ \\
\hline Other Debt Inflows & & & & $\begin{array}{c}0.169 \\
(0.169)\end{array}$ & $\begin{array}{c}0.177 \\
(0.159)\end{array}$ & & & & $\begin{array}{c}0.375 \\
(0.347)\end{array}$ & $\begin{array}{c}0.197 \\
(0.168)\end{array}$ \\
\hline Lag Dependent Variable & $\begin{array}{c}0.296 \\
(0.230)\end{array}$ & $\begin{array}{c}0.296 \\
(0.233)\end{array}$ & $\begin{array}{c}0.292 \\
(0.242)\end{array}$ & $\begin{array}{c}0.286 \\
(0.236)\end{array}$ & $\begin{array}{c}0.293 \\
(0.249)\end{array}$ & $\begin{array}{c}0.109 \\
(0.213)\end{array}$ & $\begin{array}{c}0.113 \\
(0.218)\end{array}$ & $\begin{array}{c}-0.082 \\
(0.253)\end{array}$ & $\begin{array}{c}0.076 \\
(0.196)\end{array}$ & $\begin{array}{c}0.139 \\
(0.179)\end{array}$ \\
\hline US GDP Growth & $\begin{array}{l}0.334^{*} \\
(0.192)\end{array}$ & $\begin{array}{l}0.337^{\star} \\
(0.196)\end{array}$ & $\begin{array}{c}0.334 \\
(0.198)\end{array}$ & $\begin{array}{c}0.313 \\
(0.220)\end{array}$ & $\begin{array}{c}0.314 \\
(0.221)\end{array}$ & $\begin{array}{l}-0.425 \\
(0.409)\end{array}$ & $\begin{array}{l}-0.392 \\
(0.429)\end{array}$ & $\begin{array}{l}-0.479 \\
(0.433)\end{array}$ & $\begin{array}{l}-0.548 \\
(0.484)\end{array}$ & $\begin{array}{c}0.330 \\
(0.233)\end{array}$ \\
\hline Change in Terms of Trade & $\begin{array}{l}-0.002 \\
(0.043)\end{array}$ & $\begin{array}{c}-0.002 \\
(0.043)\end{array}$ & $\begin{array}{c}-0.004 \\
(0.044)\end{array}$ & $\begin{array}{l}-0.010 \\
(0.055)\end{array}$ & $\begin{array}{l}-0.008 \\
(0.055)\end{array}$ & $\begin{array}{c}0.051 \\
(0.090)\end{array}$ & $\begin{array}{c}0.050 \\
(0.091)\end{array}$ & $\begin{array}{c}0.012 \\
(0.088)\end{array}$ & $\begin{array}{c}0.008 \\
(0.097)\end{array}$ & $\begin{array}{l}-0.035 \\
(0.059)\end{array}$ \\
\hline Policy Rate & $\begin{array}{c}-0.417^{\star \star \star} \\
(0.105)\end{array}$ & $\begin{array}{c}-0.418^{\star \star \star} \\
(0.111)\end{array}$ & $\begin{array}{c}-0.420^{* * *} \\
(0.113)\end{array}$ & $\begin{array}{c}-0.407^{\star \star *} \\
(0.121)\end{array}$ & 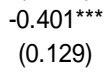 & $\begin{array}{l}-0.257^{*} \\
(0.127)\end{array}$ & $\begin{array}{c}-0.269^{*} \\
(0.133)\end{array}$ & $\begin{array}{c}-0.294^{* *} \\
(0.120)\end{array}$ & $\begin{array}{l}-0.181 \\
(0.181)\end{array}$ & 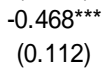 \\
\hline Foreign Reserves & $\begin{array}{c}0.141 \\
(0.141)\end{array}$ & $\begin{array}{c}0.141 \\
(0.141)\end{array}$ & $\begin{array}{c}0.138 \\
(0.148)\end{array}$ & $\begin{array}{c}0.125 \\
(0.156)\end{array}$ & $\begin{array}{c}0.129 \\
(0.162)\end{array}$ & $\begin{array}{l}-0.310 \\
(0.280)\end{array}$ & $\begin{array}{l}-0.307 \\
(0.283)\end{array}$ & $\begin{array}{l}-0.405 \\
(0.244)\end{array}$ & $\begin{array}{c}-0.399 \\
(0.280)\end{array}$ & $\begin{array}{c}0.091 \\
(0.150)\end{array}$ \\
\hline Constant & $\begin{array}{c}5.019^{* * *} \\
(1.685)\end{array}$ & $\begin{array}{c}5.020^{* * *} \\
(1.718)\end{array}$ & $\begin{array}{l}5.098^{\star *} \\
(1.857)\end{array}$ & $\begin{array}{l}4.977^{\star *} \\
(1.999)\end{array}$ & $\begin{array}{l}4.854^{\star *} \\
(2.067)\end{array}$ & $\begin{array}{c}2.282 \\
(1.653)\end{array}$ & $\begin{array}{c}2.309 \\
(1.689)\end{array}$ & $\begin{array}{l}3.529^{\star *} \\
(1.484)\end{array}$ & $\begin{array}{c}1.830 \\
(2.184)\end{array}$ & $\begin{array}{c}6.287^{\star \star *} \\
(1.318)\end{array}$ \\
\hline $\begin{array}{l}\text { Observations } \\
\text { R-squared }\end{array}$ & $\begin{array}{c}38 \\
0.606\end{array}$ & $\begin{array}{c}38 \\
0.606\end{array}$ & $\begin{array}{c}38 \\
0.606\end{array}$ & $\begin{array}{c}38 \\
0.613\end{array}$ & $\begin{array}{c}38 \\
0.614\end{array}$ & $\begin{array}{c}38 \\
0.346\end{array}$ & $\begin{array}{c}38 \\
0.347\end{array}$ & $\begin{array}{c}38 \\
0.404\end{array}$ & $\begin{array}{c}38 \\
0.464\end{array}$ & $\begin{array}{c}38 \\
0.582\end{array}$ \\
\hline
\end{tabular}

Notes: Dependent variables are output and credit growth. Gross capital inflows are lagged by one period. Robust standard errors in are parentheses. ${ }^{* * *} p<0.01,{ }^{* *} p<0.05,{ }^{*} p<0.1$. 
Table 5: OLS Estimation of Output and Credit Growth on Net Capital Inflows

\begin{tabular}{|c|c|c|c|c|c|c|c|c|c|c|}
\hline VARIABLES & \multicolumn{5}{|c|}{ Output Growth } & \multicolumn{5}{|c|}{ Credit Growth } \\
\hline Inflows & $\begin{array}{c}0.315^{\star \star *} \\
(0.102)\end{array}$ & & & & & $\begin{array}{c}1.048^{\star \star \star} \\
(0.303)\end{array}$ & & & & \\
\hline Bond Inflows & & $\begin{array}{c}0.279 \\
(0.299)\end{array}$ & & $\begin{array}{c}0.324 \\
(0.360)\end{array}$ & & & $\begin{array}{c}2.114^{\star \star *} \\
(0.739)\end{array}$ & & $\begin{array}{l}1.890^{\star *} \\
(0.736)\end{array}$ & \\
\hline Private Bond Inflows & & & $\begin{array}{c}0.509 \\
(0.382)\end{array}$ & & $\begin{array}{c}0.736 \\
(0.509)\end{array}$ & & & $\begin{array}{c}3.580^{\star \star \star} \\
(0.746)\end{array}$ & & $\begin{array}{l}0.894^{*} \\
(0.497)\end{array}$ \\
\hline Public Bond Inflows & & & $\begin{array}{c}0.079 \\
(0.363)\end{array}$ & & $\begin{array}{c}0.043 \\
(0.427)\end{array}$ & & & $\begin{array}{c}0.787 \\
(0.521)\end{array}$ & & $\begin{array}{c}0.018 \\
(0.450)\end{array}$ \\
\hline Non-Bond Inflows & & $\begin{array}{c}0.321^{\star \star \star} \\
(0.106)\end{array}$ & $\begin{array}{l}0.292^{* *} \\
(0.122)\end{array}$ & & & & $\begin{array}{c}0.849^{\star \star \star} \\
(0.269)\end{array}$ & $\begin{array}{c}0.724^{\star \star *} \\
(0.252)\end{array}$ & & \\
\hline FDI Inflows & & & & $\begin{array}{c}0.503 \\
(0.551)\end{array}$ & $\begin{array}{c}0.651 \\
(0.556)\end{array}$ & & & & $\begin{array}{c}0.334 \\
(1.003)\end{array}$ & $\begin{array}{c}0.779 \\
(0.572)\end{array}$ \\
\hline Portfolio Equity Inflows & & & & $\begin{array}{c}0.032 \\
(0.450)\end{array}$ & $\begin{array}{l}-0.292 \\
(0.643)\end{array}$ & & & & $\begin{array}{l}2.083^{\star \star} \\
(0.804)\end{array}$ & $\begin{array}{l}-0.547 \\
(0.647)\end{array}$ \\
\hline Other Debt Inflows & & & & $\begin{array}{c}0.330^{\star \star \star} \\
(0.114)\end{array}$ & $\begin{array}{l}0.292^{* *} \\
(0.125)\end{array}$ & & & & $\begin{array}{c}0.807^{\star \star \star} \\
(0.290)\end{array}$ & $\begin{array}{l}0.279^{\star \star} \\
(0.130)\end{array}$ \\
\hline Lag Dependent Variable & $\begin{array}{c}0.305 \\
(0.214)\end{array}$ & $\begin{array}{c}0.305 \\
(0.217)\end{array}$ & $\begin{array}{c}0.290 \\
(0.224)\end{array}$ & $\begin{array}{c}0.295 \\
(0.216)\end{array}$ & $\begin{array}{c}0.261 \\
(0.221)\end{array}$ & $\begin{array}{c}0.025 \\
(0.202)\end{array}$ & $\begin{array}{c}0.075 \\
(0.187)\end{array}$ & $\begin{array}{l}-0.022 \\
(0.140)\end{array}$ & $\begin{array}{c}0.065 \\
(0.171)\end{array}$ & $\begin{array}{c}0.053 \\
(0.128)\end{array}$ \\
\hline US GDP Growth & $\begin{array}{c}0.466^{\star \star \star} \\
(0.155)\end{array}$ & $\begin{array}{c}0.467^{\star \star * *} \\
(0.159)\end{array}$ & $\begin{array}{c}0.493^{\star \star \star} \\
(0.172)\end{array}$ & $\begin{array}{l}0.460^{* *} \\
(0.183)\end{array}$ & $\begin{array}{l}0.492^{\star *} \\
(0.203)\end{array}$ & $\begin{array}{c}0.033 \\
(0.439)\end{array}$ & $\begin{array}{l}-0.016 \\
(0.376)\end{array}$ & $\begin{array}{c}0.167 \\
(0.352)\end{array}$ & $\begin{array}{l}-0.009 \\
(0.404)\end{array}$ & $\begin{array}{l}0.517^{\star *} \\
(0.199)\end{array}$ \\
\hline Change in Terms of Trade & $\begin{array}{l}-0.024 \\
(0.042)\end{array}$ & $\begin{array}{l}-0.024 \\
(0.045)\end{array}$ & $\begin{array}{l}-0.023 \\
(0.044)\end{array}$ & $\begin{array}{l}-0.028 \\
(0.042)\end{array}$ & $\begin{array}{l}-0.030 \\
(0.040)\end{array}$ & $\begin{array}{l}-0.030 \\
(0.081)\end{array}$ & $\begin{array}{l}-0.050 \\
(0.083)\end{array}$ & $\begin{array}{l}-0.040 \\
(0.069)\end{array}$ & $\begin{array}{l}-0.043 \\
(0.080)\end{array}$ & $\begin{array}{l}-0.064 \\
(0.046)\end{array}$ \\
\hline Policy Rate & $\begin{array}{c}-0.520^{\star \star \star *} \\
(0.116)\end{array}$ & $\begin{array}{c}-0.522^{* \star *} \\
(0.119)\end{array}$ & $\begin{array}{c}-0.534^{\star \star *} \\
(0.121)\end{array}$ & $\begin{array}{c}-0.536^{\star \star *} \\
(0.120)\end{array}$ & $\begin{array}{c}-0.570^{\star \star *} \\
(0.122)\end{array}$ & $\begin{array}{c}-0.614^{\star \star \star} \\
(0.181)\end{array}$ & $\begin{array}{c}-0.569^{* \star *} \\
(0.180)\end{array}$ & $\begin{array}{c}-0.636^{\star \star * *} \\
(0.163)\end{array}$ & $\begin{array}{c}-0.526^{\star *} \\
(0.202)\end{array}$ & $\begin{array}{c}-0.651^{* \star *} \\
(0.107)\end{array}$ \\
\hline Foreign Reserves & $\begin{array}{l}-0.058 \\
(0.153)\end{array}$ & $\begin{array}{l}-0.052 \\
(0.166)\end{array}$ & $\begin{array}{l}-0.031 \\
(0.165)\end{array}$ & $\begin{array}{l}-0.036 \\
(0.192)\end{array}$ & $\begin{array}{l}0.015 \\
(0.202)\end{array}$ & $\begin{array}{l}-0.992^{\star \star} \\
(0.363)\end{array}$ & $\begin{array}{c}-1.139^{\star \star *} \\
(0.379)\end{array}$ & $\begin{array}{c}-1.013^{\star \star \star} \\
(0.274)\end{array}$ & $\begin{array}{c}-1.202^{\star \star \star \star} \\
(0.402)\end{array}$ & $\begin{array}{l}-0.013 \\
(0.206)\end{array}$ \\
\hline Constant & $\begin{array}{l}6.011^{\star \star *} \\
(1.687)\end{array}$ & $\begin{array}{l}6.012^{\star \star \star} \\
(1.713)\end{array}$ & $\begin{array}{c}6.262^{* \star *} \\
(1.837)\end{array}$ & $\begin{array}{l}6.141^{* * *} \\
(1.734)\end{array}$ & $\begin{array}{l}6.669^{* * *} \\
(1.897)\end{array}$ & $\begin{array}{l}5.543^{\star \star \star} \\
(1.707)\end{array}$ & $\begin{array}{c}5.550^{\star \star *} \\
(1.756)\end{array}$ & $\begin{array}{l}6.576^{\star \star \star} \\
(1.648)\end{array}$ & $\begin{array}{l}5.251^{\star \star} \\
(1.947)\end{array}$ & $\begin{array}{l}8.492^{\star * *} \\
(0.990)\end{array}$ \\
\hline $\begin{array}{l}\text { Observations } \\
\text { R-squared }\end{array}$ & $\begin{array}{c}39 \\
0.653\end{array}$ & $\begin{array}{c}39 \\
0.653\end{array}$ & $\begin{array}{c}39 \\
0.661\end{array}$ & $\begin{array}{c}39 \\
0.657\end{array}$ & $\begin{array}{c}39 \\
0.672\end{array}$ & $\begin{array}{c}39 \\
0.550\end{array}$ & $\begin{array}{c}39 \\
0.597\end{array}$ & $\begin{array}{c}39 \\
0.713\end{array}$ & $\begin{array}{c}39 \\
0.615\end{array}$ & $\begin{array}{c}39 \\
0.629\end{array}$ \\
\hline
\end{tabular}

Notes: Dependent variables are output and credit growth. Net inflows are computed as liabilities minus assets following Balance of Payment Statistics Manual 6 data presentation. Robust standard errors in are parentheses. ${ }^{* * *} p<0.01, * * p<0.05, * p<0.1$. 
Table 6: OLS Estimation Output and Credit Growth on Gross Capital Inflows (Excluding Zeros for Public Bond Inflows and Portfolio Equity Inflows)

\begin{tabular}{|c|c|c|c|c|c|c|c|c|c|c|}
\hline VARIABLES & \multicolumn{5}{|c|}{ Output Growth } & \multicolumn{4}{|c|}{ Credit Growth } & (10) \\
\hline Inflows & $\begin{array}{l}0.266^{\star *} \\
(0.099)\end{array}$ & & & & & $\begin{array}{c}0.868^{\star \star *} \\
(0.276)\end{array}$ & & & & \\
\hline Bond Inflows & & $\begin{array}{c}0.137 \\
(0.260)\end{array}$ & & $\begin{array}{c}0.263 \\
(0.226)\end{array}$ & & & $\begin{array}{l}1.503^{\star *} \\
(0.612)\end{array}$ & & $\begin{array}{c}1.766^{\star \star *} \\
(0.368)\end{array}$ & \\
\hline Private Bond Inflows & & & $\begin{array}{c}0.358 \\
(0.727)\end{array}$ & & $\begin{array}{c}0.110 \\
(0.786)\end{array}$ & & & $\begin{array}{c}0.453 \\
(2.106)\end{array}$ & & $\begin{array}{l}-0.022 \\
(0.732)\end{array}$ \\
\hline Public Bond Inflows & & & $\begin{array}{l}-0.304 \\
(0.456)\end{array}$ & & $\begin{array}{l}-0.207 \\
(0.369)\end{array}$ & & & $\begin{array}{l}2.040^{* *} \\
(0.856)\end{array}$ & & $\begin{array}{l}-0.031 \\
(0.281)\end{array}$ \\
\hline Non-Bond Inflows & & $\begin{array}{l}0.294^{\star *} \\
(0.113)\end{array}$ & $\begin{array}{c}0.328 \\
(0.285)\end{array}$ & & & & $\begin{array}{l}0.723^{\star *} \\
(0.272)\end{array}$ & $\begin{array}{l}2.221^{\star \star} \\
(0.770)\end{array}$ & & \\
\hline FDI Inflows & & & & $\begin{array}{l}-0.430 \\
(0.459)\end{array}$ & $\begin{array}{l}-0.589 \\
(0.465)\end{array}$ & & & & $\begin{array}{l}-0.011 \\
(0.562)\end{array}$ & $\begin{array}{l}-0.683 \\
(0.403)\end{array}$ \\
\hline Portfolio Equity Inflows & & & & $\begin{array}{c}0.220 \\
(0.406)\end{array}$ & $\begin{array}{c}0.026 \\
(0.617)\end{array}$ & & & & $\begin{array}{c}0.196 \\
(0.815)\end{array}$ & $\begin{array}{c}0.158 \\
(0.623)\end{array}$ \\
\hline Other Debt Inflows & & & & $\begin{array}{l}0.361^{\star *} \\
(0.131)\end{array}$ & $\begin{array}{c}0.455 \\
(0.282)\end{array}$ & & & & $\begin{array}{c}1.726^{\star \star \star} \\
(0.204)\end{array}$ & $\begin{array}{l}0.540^{\star} \\
(0.271)\end{array}$ \\
\hline Lag Dependent Variable & $\begin{array}{c}0.287 \\
(0.221)\end{array}$ & $\begin{array}{c}0.277 \\
(0.233)\end{array}$ & $\begin{array}{l}-0.324 \\
(0.214)\end{array}$ & $\begin{array}{c}0.155 \\
(0.176)\end{array}$ & $\begin{array}{l}-0.262 \\
(0.224)\end{array}$ & $\begin{array}{c}0.093 \\
(0.194)\end{array}$ & $\begin{array}{c}0.117 \\
(0.192)\end{array}$ & $\begin{array}{l}-0.058 \\
(0.124)\end{array}$ & $\begin{array}{l}-0.006 \\
(0.096)\end{array}$ & $\begin{array}{l}-0.073 \\
(0.049)\end{array}$ \\
\hline US GDP Growth & $\begin{array}{l}0.397^{\star *} \\
(0.161)\end{array}$ & $\begin{array}{l}0.414^{\star *} \\
(0.167)\end{array}$ & $\begin{array}{l}0.569^{\star \star} \\
(0.235)\end{array}$ & $\begin{array}{c}0.665^{\star \star \star} \\
(0.118)\end{array}$ & $\begin{array}{l}0.622^{* *} \\
(0.218)\end{array}$ & $\begin{array}{l}-0.206 \\
(0.425)\end{array}$ & $\begin{array}{l}-0.288 \\
(0.376)\end{array}$ & $\begin{array}{c}-2.218^{\star \star \star} \\
(0.541)\end{array}$ & $\begin{array}{c}-1.077^{\star *} \\
(0.370)\end{array}$ & $\begin{array}{l}0.579^{\star *} \\
(0.207)\end{array}$ \\
\hline Change in Terms of Trade & $\begin{array}{l}-0.023 \\
(0.043)\end{array}$ & $\begin{array}{l}-0.020 \\
(0.044)\end{array}$ & $\begin{array}{l}-0.119 \\
(0.077)\end{array}$ & $\begin{array}{l}-0.041 \\
(0.046)\end{array}$ & $\begin{array}{l}-0.118^{\star \star} \\
(0.046)\end{array}$ & $\begin{array}{l}-0.008 \\
(0.086)\end{array}$ & $\begin{array}{l}-0.026 \\
(0.090)\end{array}$ & $\begin{array}{l}-0.221 \\
(0.142)\end{array}$ & $\begin{array}{l}-0.171 \\
(0.099)\end{array}$ & $\begin{array}{c}-0.114^{* \star *} \\
(0.031)\end{array}$ \\
\hline Policy Rate & $\begin{array}{c}-0.458^{\star \star \star} \\
(0.114)\end{array}$ & $\begin{array}{c}-0.470^{\star \star *} \\
(0.123)\end{array}$ & $\begin{array}{c}-0.448^{\star \star \star} \\
(0.121)\end{array}$ & $\begin{array}{c}-0.495^{\star \star \star} \\
(0.074)\end{array}$ & $\begin{array}{c}-0.406^{\star \star \star} \\
(0.081)\end{array}$ & $\begin{array}{c}-0.396^{* *} \\
(0.162)\end{array}$ & $\begin{array}{l}-0.354^{* \star} \\
(0.164)\end{array}$ & $\begin{array}{l}-0.340 \\
(0.213)\end{array}$ & $\begin{array}{c}-0.485^{\star \star *} \\
(0.130)\end{array}$ & $\begin{array}{c}-0.358^{* \star *} \\
(0.067)\end{array}$ \\
\hline Foreign Reserves & $\begin{array}{l}-0.068 \\
(0.168)\end{array}$ & $\begin{array}{l}-0.060 \\
(0.171)\end{array}$ & $\begin{array}{l}-0.123 \\
(0.237)\end{array}$ & $\begin{array}{l}-0.180 \\
(0.151)\end{array}$ & $\begin{array}{l}-0.104 \\
(0.190)\end{array}$ & $\begin{array}{l}-0.985^{\star *} \\
(0.367)\end{array}$ & $\begin{array}{c}-1.029^{\star \star *} \\
(0.361)\end{array}$ & $\begin{array}{c}-1.962^{\star \star \star} \\
(0.513)\end{array}$ & $\begin{array}{c}-1.428^{\star \star *} \\
(0.220)\end{array}$ & $\begin{array}{l}-0.158 \\
(0.208)\end{array}$ \\
\hline Constant & $\begin{array}{l}5.413^{\star \star \star} \\
(1.745)\end{array}$ & $\begin{array}{c}5.501^{\star * *} \\
(1.845)\end{array}$ & $\begin{array}{l}7.693^{\star \star \star} \\
(1.609)\end{array}$ & $\begin{array}{l}6.446^{* * *} \\
(1.183)\end{array}$ & $\begin{array}{l}8.376^{\star \star *} \\
(1.154)\end{array}$ & $\begin{array}{l}3.213^{\star} \\
(1.737)\end{array}$ & $\begin{array}{l}3.118^{\star} \\
(1.723)\end{array}$ & $\begin{array}{l}5.154^{\star \star \star} \\
(1.637)\end{array}$ & $\begin{array}{l}6.582^{\star \star \star} \\
(1.205)\end{array}$ & $\begin{array}{c}6.997^{\star \star \star \star} \\
(0.559)\end{array}$ \\
\hline $\begin{array}{l}\text { Observations } \\
\text { R-squared }\end{array}$ & $\begin{array}{c}39 \\
0.638\end{array}$ & $\begin{array}{c}39 \\
0.640\end{array}$ & $\begin{array}{c}20 \\
0.761\end{array}$ & $\begin{array}{c}26 \\
0.797\end{array}$ & $\begin{array}{c}20 \\
0.872\end{array}$ & $\begin{array}{c}39 \\
0.509\end{array}$ & $\begin{array}{c}39 \\
0.530\end{array}$ & $\begin{array}{c}20 \\
0.892\end{array}$ & $\begin{array}{c}26 \\
0.862\end{array}$ & $\begin{array}{c}20 \\
0.867\end{array}$ \\
\hline
\end{tabular}

Notes: Dependent variables are output and credit growth. The values of zero were removed for public bond inflows and portfolio equity inflows whenever data is unavailable. Consequently, the sample size for specifications (3), (4), (5), (8), (9), and (10) are smaller than the baseline sample. Robust standard errors in are parentheses. ${ }^{* * *} p<0.01,{ }^{* *} p<0.05, * p<0.1$. 
Table 7: OLS Estimation of Output Growth on Gross Capital Inflows Period Split

\begin{tabular}{|c|c|c|c|c|c|c|c|c|c|c|}
\hline VARIABLES & (1) & (2) & $\begin{array}{c}(3) \\
\text { Period } 1 \\
\end{array}$ & (4) & (5) & (6) & (7) & $\begin{array}{c}(8) \\
\text { Period } 2 \\
\end{array}$ & (9) & (10) \\
\hline Inflows & $\begin{array}{l}-0.029 \\
(0.123)\end{array}$ & & & & & $\begin{array}{c}0.118 \\
(0.268)\end{array}$ & & & & \\
\hline Bond Inflows & & $\begin{array}{c}0.404 \\
(0.445)\end{array}$ & & $\begin{array}{l}1.067^{*} \\
(0.567)\end{array}$ & & & $\begin{array}{l}-0.151 \\
(0.329)\end{array}$ & & $\begin{array}{l}-0.044 \\
(0.208)\end{array}$ & \\
\hline Private Bond Inflows & & & $\begin{array}{c}0.520 \\
(0.662)\end{array}$ & & $\begin{array}{l}1.018^{*} \\
(0.492)\end{array}$ & & & $\begin{array}{c}0.421 \\
(0.764)\end{array}$ & & $\begin{array}{c}0.126 \\
(0.834)\end{array}$ \\
\hline Public Bond Inflows & & & $\begin{array}{l}-1.020 \\
(2.602)\end{array}$ & & $\begin{array}{c}3.960 \\
(2.204)\end{array}$ & & & $\begin{array}{l}-0.399 \\
(0.514)\end{array}$ & & $\begin{array}{l}-0.103 \\
(0.389)\end{array}$ \\
\hline Non-Bond Inflows & & $\begin{array}{l}-0.145 \\
(0.189)\end{array}$ & $\begin{array}{l}-0.146 \\
(0.196)\end{array}$ & & & & $\begin{array}{c}0.393 \\
(0.344)\end{array}$ & $\begin{array}{c}0.236 \\
(0.442)\end{array}$ & & \\
\hline FDI Inflows & & & & $\begin{array}{l}1.042^{*} \\
(0.550)\end{array}$ & $\begin{array}{l}1.350^{\star *} \\
(0.585)\end{array}$ & & & & $\begin{array}{l}-0.492 \\
(0.397)\end{array}$ & $\begin{array}{l}-0.511 \\
(0.433)\end{array}$ \\
\hline Portfolio Equity Inflows & & & & $\begin{array}{c}-2.091^{\star *} \\
(0.742)\end{array}$ & $\begin{array}{c}-2.596^{\star *} \\
(0.900)\end{array}$ & & & & $\begin{array}{c}0.867 \\
(0.720)\end{array}$ & $\begin{array}{c}0.712 \\
(1.222)\end{array}$ \\
\hline Other Debt Inflows & & & & $\begin{array}{l}-0.035 \\
(0.153)\end{array}$ & $\begin{array}{l}-0.005 \\
(0.154)\end{array}$ & & & & $\begin{array}{l}0.769^{\star *} \\
(0.308)\end{array}$ & $\begin{array}{c}0.736 \\
(0.417)\end{array}$ \\
\hline Lag Dependent Variable & $\begin{array}{l}0.462^{\star *} \\
(0.214)\end{array}$ & $\begin{array}{l}0.482^{* *} \\
(0.213)\end{array}$ & $\begin{array}{l}0.485^{\star *} \\
(0.220)\end{array}$ & $\begin{array}{c}0.366 \\
(0.206)\end{array}$ & $\begin{array}{c}0.330 \\
(0.236)\end{array}$ & $\begin{array}{l}-0.236 \\
(0.209)\end{array}$ & $\begin{array}{l}-0.344 \\
(0.191)\end{array}$ & $\begin{array}{l}-0.364 \\
(0.223)\end{array}$ & $\begin{array}{l}-0.205 \\
(0.223)\end{array}$ & $\begin{array}{l}-0.209 \\
(0.242)\end{array}$ \\
\hline US GDP Growth & $\begin{array}{c}0.268 \\
(0.273)\end{array}$ & $\begin{array}{c}0.180 \\
(0.313)\end{array}$ & $\begin{array}{c}0.179 \\
(0.336)\end{array}$ & $\begin{array}{c}0.136 \\
(0.359)\end{array}$ & $\begin{array}{c}0.125 \\
(0.357)\end{array}$ & $\begin{array}{l}0.634^{\star *} \\
(0.250)\end{array}$ & $\begin{array}{l}0.512^{*} \\
(0.254)\end{array}$ & $\begin{array}{l}0.627^{\star} \\
(0.291)\end{array}$ & $\begin{array}{l}0.453^{\star \star} \\
(0.172)\end{array}$ & $\begin{array}{c}0.485 \\
(0.296)\end{array}$ \\
\hline Change in Terms of Trade & $\begin{array}{l}-0.016 \\
(0.043)\end{array}$ & $\begin{array}{l}-0.024 \\
(0.045)\end{array}$ & $\begin{array}{l}-0.024 \\
(0.048)\end{array}$ & $\begin{array}{l}-0.046 \\
(0.047)\end{array}$ & $\begin{array}{l}-0.051 \\
(0.049)\end{array}$ & $\begin{array}{c}-0.133^{\star \star} \\
(0.052)\end{array}$ & $\begin{array}{c}-0.143^{\star *} \\
(0.057)\end{array}$ & $\begin{array}{l}-0.115 \\
(0.077)\end{array}$ & $\begin{array}{c}-0.138^{\star \star \star} \\
(0.041)\end{array}$ & $\begin{array}{l}-0.131^{*} \\
(0.060)\end{array}$ \\
\hline Policy Rate & $\begin{array}{c}-0.767^{\star \star \star} \\
(0.143)\end{array}$ & $\begin{array}{c}-0.755^{\star \star *} \\
(0.143)\end{array}$ & $\begin{array}{c}-0.752^{\star \star \star *} \\
(0.152)\end{array}$ & $\begin{array}{c}-0.729^{\star \star \star} \\
(0.166)\end{array}$ & $\begin{array}{c}-0.728^{\star \star \star \star} \\
(0.172)\end{array}$ & $\begin{array}{c}-0.564^{\star \star \star} \\
(0.137)\end{array}$ & $\begin{array}{c}-0.517^{\star \star \star} \\
(0.155)\end{array}$ & $\begin{array}{c}-0.497^{\star \star \star} \\
(0.152)\end{array}$ & $\begin{array}{l}-0.331^{\star \star} \\
(0.124)\end{array}$ & $\begin{array}{l}-0.324^{* *} \\
(0.114)\end{array}$ \\
\hline Foreign Reserves & $\begin{array}{c}0.111 \\
(0.245)\end{array}$ & $\begin{array}{c}0.146 \\
(0.260)\end{array}$ & $\begin{array}{c}0.179 \\
(0.274)\end{array}$ & $\begin{array}{c}0.181 \\
(0.239)\end{array}$ & $\begin{array}{c}0.128 \\
(0.261)\end{array}$ & $\begin{array}{l}-0.016 \\
(0.192)\end{array}$ & $\begin{array}{l}-0.079 \\
(0.212)\end{array}$ & $\begin{array}{c}0.011 \\
(0.260)\end{array}$ & $\begin{array}{l}-0.268 \\
(0.161)\end{array}$ & $\begin{array}{l}-0.243 \\
(0.243)\end{array}$ \\
\hline Constant & $\begin{array}{c}11.836^{\star \star \star} \\
(2.342)\end{array}$ & $\begin{array}{c}12.213^{\star \star \star} \\
(2.373)\end{array}$ & $\begin{array}{c}12.086^{\star * \star} \\
(2.492)\end{array}$ & $\begin{array}{c}10.973^{\star \star \star} \\
(2.589)\end{array}$ & $\begin{array}{c}10.895^{\star \star \star} \\
(2.695)\end{array}$ & $\begin{array}{l}7.587^{\star \star \star} \\
(1.764)\end{array}$ & $\begin{array}{c}7.950^{\star \star \star} \\
(1.590)\end{array}$ & $\begin{array}{l}7.988^{* \star *} \\
(1.731)\end{array}$ & $\begin{array}{l}7.854^{\star \star \star} \\
(1.185)\end{array}$ & $\begin{array}{c}7.842^{\star \star \star} \\
(1.286)\end{array}$ \\
\hline Observations & $\begin{array}{c}21 \\
0800\end{array}$ & 21 & 21 & 21 & $\begin{array}{c}21 \\
0858\end{array}$ & $\begin{array}{c}18 \\
075 ?\end{array}$ & 18 & 18 & 18 & $\begin{array}{c}18 \\
0894\end{array}$ \\
\hline
\end{tabular}

Notes: Output growth refers to the year-on-year change of real GDP. Period 1 covers 1977-1997; while Period 2 includes 1998-2015. Robust standard errors are in parentheses. ${ }^{* * *} p<0.01,{ }^{* *} p<0.05,{ }^{*} p<0.1$. 
Table 8: OLS Estimation of Credit Growth on Gross Capital Inflows Period Split

\begin{tabular}{|c|c|c|c|c|c|c|c|c|c|c|}
\hline VARIABLES & (1) & (2) & $\begin{array}{c}\text { (3) } \\
\text { Period } 1 \\
\end{array}$ & (4) & (5) & (6) & (7) & $\begin{array}{c}\text { (8) } \\
\text { Period } 2 \\
\end{array}$ & (9) & (10) \\
\hline Inflows & $\begin{array}{c}0.469 \\
(0.305)\end{array}$ & & & & & $\begin{array}{l}1.149^{\star \star \star} \\
(0.284)\end{array}$ & & & & \\
\hline Bond Inflows & & $\begin{array}{c}2.413^{\star \star \star} \\
(0.685)\end{array}$ & & $\begin{array}{c}2.541 \\
(1.456)\end{array}$ & & & $\begin{array}{l}1.223^{\star *} \\
(0.444)\end{array}$ & & $\begin{array}{c}1.646^{\star \star \star} \\
(0.271)\end{array}$ & \\
\hline Private Bond Inflows & & & $\begin{array}{l}2.143^{\star *} \\
(0.753)\end{array}$ & & $\begin{array}{c}0.026 \\
(0.861)\end{array}$ & & & $\begin{array}{l}-0.584 \\
(2.471)\end{array}$ & & $\begin{array}{c}0.026 \\
(0.745)\end{array}$ \\
\hline Public Bond Inflows & & & $\begin{array}{l}5.441 \\
(3.517)\end{array}$ & & $\begin{array}{l}3.964 \\
(2.485)\end{array}$ & & & $\begin{array}{l}1.918^{\star *} \\
(0.777)\end{array}$ & & $\begin{array}{c}0.048 \\
(0.322)\end{array}$ \\
\hline Non-Bond Inflows & & $\begin{array}{c}0.051 \\
(0.301)\end{array}$ & $\begin{array}{c}0.036 \\
(0.305)\end{array}$ & & & & $\begin{array}{l}1.051^{\star *} \\
(0.349)\end{array}$ & $\begin{array}{l}1.518^{\star \star} \\
(0.570)\end{array}$ & & \\
\hline FDI Inflows & & & & $\begin{array}{c}0.879 \\
(1.903)\end{array}$ & $\begin{array}{c}0.710 \\
(0.836)\end{array}$ & & & & $\begin{array}{c}0.082 \\
(0.429)\end{array}$ & $\begin{array}{l}-0.589 \\
(0.384)\end{array}$ \\
\hline Portfolio Equity Inflows & & & & $\begin{array}{l}-0.513 \\
(2.036)\end{array}$ & $\begin{array}{l}-2.106 \\
(1.392)\end{array}$ & & & & $\begin{array}{l}-2.160^{* *} \\
(0.658)\end{array}$ & $\begin{array}{c}0.796 \\
(1.048)\end{array}$ \\
\hline Other Debt Inflows & & & & $\begin{array}{c}0.144 \\
(0.510)\end{array}$ & $\begin{array}{l}-0.224 \\
(0.161)\end{array}$ & & & & $\begin{array}{c}2.309^{\star \star \star} \\
(0.283)\end{array}$ & $\begin{array}{l}0.788^{*} \\
(0.401)\end{array}$ \\
\hline Lag Dependent Variable & $\begin{array}{l}0.348^{\star} \\
(0.179)\end{array}$ & $\begin{array}{l}0.292^{*} \\
(0.157)\end{array}$ & $\begin{array}{c}0.308 \\
(0.177)\end{array}$ & $\begin{array}{c}0.220 \\
(0.299)\end{array}$ & $\begin{array}{l}0.417^{\star *} \\
(0.135)\end{array}$ & $\begin{array}{l}-0.154 \\
(0.127)\end{array}$ & $\begin{array}{l}-0.148 \\
(0.129)\end{array}$ & $\begin{array}{l}-0.157 \\
(0.125)\end{array}$ & $\begin{array}{l}-0.092^{*} \\
(0.046)\end{array}$ & $\begin{array}{l}-0.050 \\
(0.049)\end{array}$ \\
\hline US GDP Growth & $\begin{array}{c}0.600 \\
(0.391)\end{array}$ & $\begin{array}{c}0.285 \\
(0.225)\end{array}$ & $\begin{array}{c}0.273 \\
(0.248)\end{array}$ & $\begin{array}{c}0.275 \\
(0.226)\end{array}$ & $\begin{array}{c}0.096 \\
(0.306)\end{array}$ & $\begin{array}{c}-1.624^{\star \star *} \\
(0.305)\end{array}$ & $\begin{array}{c}-1.581^{* \star *} \\
(0.340)\end{array}$ & $\begin{array}{c}-1.931^{\star \star \star} \\
(0.448)\end{array}$ & $\begin{array}{c}-1.758^{\star \star \star} \\
(0.168)\end{array}$ & $\begin{array}{c}0.458 \\
(0.263)\end{array}$ \\
\hline Change in Terms of Trade & $\begin{array}{l}-0.026 \\
(0.078)\end{array}$ & $\begin{array}{l}-0.073 \\
(0.066)\end{array}$ & $\begin{array}{l}-0.072 \\
(0.072)\end{array}$ & $\begin{array}{l}-0.080 \\
(0.073)\end{array}$ & $\begin{array}{l}-0.077^{*} \\
(0.041)\end{array}$ & $\begin{array}{l}-0.120 \\
(0.150)\end{array}$ & $\begin{array}{l}-0.120 \\
(0.158)\end{array}$ & $\begin{array}{l}-0.208 \\
(0.128)\end{array}$ & $\begin{array}{c}-0.165^{\star \star \star} \\
(0.037)\end{array}$ & $\begin{array}{c}-0.126^{* \star} \\
(0.045)\end{array}$ \\
\hline Policy Rate & $\begin{array}{l}-0.935^{* *} \\
(0.361)\end{array}$ & $\begin{array}{l}-0.892^{* *} \\
(0.311)\end{array}$ & $\begin{array}{l}-0.902^{* *} \\
(0.332)\end{array}$ & $\begin{array}{l}-0.836^{* *} \\
(0.351)\end{array}$ & $\begin{array}{c}-0.972^{\star \star *} \\
(0.141)\end{array}$ & $\begin{array}{l}-0.504^{\star \star} \\
(0.228)\end{array}$ & $\begin{array}{c}-0.527^{\star \star} \\
(0.233)\end{array}$ & $\begin{array}{l}-0.596^{*} \\
(0.303)\end{array}$ & $\begin{array}{l}-0.106 \\
(0.110)\end{array}$ & $\begin{array}{l}-0.292^{\star *} \\
(0.109)\end{array}$ \\
\hline Foreign Reserves & $\begin{array}{l}-0.638^{*} \\
(0.334)\end{array}$ & $\begin{array}{l}-0.565 \\
(0.333)\end{array}$ & $\begin{array}{l}-0.623 \\
(0.384)\end{array}$ & $\begin{array}{l}-0.581 \\
(0.368)\end{array}$ & $\begin{array}{c}0.138 \\
(0.202)\end{array}$ & $\begin{array}{c}-1.376^{\star \star \star} \\
(0.317)\end{array}$ & $\begin{array}{c}-1.353^{\star \star * *} \\
(0.335)\end{array}$ & $\begin{array}{c}-1.617^{\star \star \star} \\
(0.436)\end{array}$ & $\begin{array}{c}-1.773^{\star \star *} \\
(0.210)\end{array}$ & $\begin{array}{l}-0.278 \\
(0.281)\end{array}$ \\
\hline Constant & $\begin{array}{l}10.886^{*} \\
(6.082)\end{array}$ & $\begin{array}{c}12.331^{* *} \\
(5.652)\end{array}$ & $\begin{array}{l}12.731^{*} \\
(6.003)\end{array}$ & $\begin{array}{l}10.600 \\
(8.019)\end{array}$ & $\begin{array}{c}16.864^{* \star *} \\
(2.047)\end{array}$ & $\begin{array}{l}6.138^{\star \star *} \\
(1.441)\end{array}$ & $\begin{array}{l}6.240^{\star \star *} \\
(1.400)\end{array}$ & $\begin{array}{l}6.501^{\star \star \star} \\
(1.489)\end{array}$ & $\begin{array}{c}7.368^{\star \star *} \\
(0.622)\end{array}$ & $\begin{array}{c}6.753^{* * *} \\
(0.683)\end{array}$ \\
\hline Observations & 21 & 21 & 21 & 21 & 21 & 18 & 18 & 18 & 18 & 18 \\
\hline R-squared & 0.705 & 0.803 & 0.808 & 0.808 & 0.901 & 0.824 & 0.825 & 0.849 & 0.971 & 0.886 \\
\hline
\end{tabular}

Notes: Credit growth refers to the difference between current year and previous year domestic credit provided by the banking sector. Period 1 covers 1977-1997; while Period 2 includes 1998-2015. Robust standard errors are in parentheses. ${ }^{* * *} p<0.01,{ }^{* *} p<0.05,{ }^{*} p<0.1$. 
Table 9: OLS Estimation of Output and Credit Growth on Gross Capital Inflows (Using quarterly data)

\begin{tabular}{|c|c|c|c|c|c|c|c|c|c|c|}
\hline VARIABLES & (1) & \multicolumn{4}{|c|}{ Output Growth } & (6) & \multicolumn{3}{|c|}{ Credit Growth } & (10) \\
\hline Inflows & $\begin{array}{c}0.614^{\star * *} \\
(0.199)\end{array}$ & & & & & $\begin{array}{c}0.971^{\star \star *} \\
(0.336)\end{array}$ & & & & \\
\hline Bond Inflows & & $\begin{array}{c}0.139 \\
(0.372)\end{array}$ & & $\begin{array}{c}0.083 \\
(0.415)\end{array}$ & & & $\begin{array}{c}0.441 \\
(0.643)\end{array}$ & & $\begin{array}{c}0.470 \\
(0.631)\end{array}$ & \\
\hline Private Bond Inflows & & & $\begin{array}{l}0.973^{\star} \\
(0.510)\end{array}$ & & $\begin{array}{l}0.929^{\star} \\
(0.505)\end{array}$ & & & $\begin{array}{c}2.741^{\star \star *} \\
(0.968)\end{array}$ & & $\begin{array}{c}2.688^{\star \star *} \\
(0.936)\end{array}$ \\
\hline Public Bond Inflows & & & $\begin{array}{l}-0.362 \\
(0.370)\end{array}$ & & $\begin{array}{l}-0.457 \\
(0.459)\end{array}$ & & & $\begin{array}{l}-0.926 \\
(0.588)\end{array}$ & & $\begin{array}{l}-0.917 \\
(0.632)\end{array}$ \\
\hline Non-Bond Inflows & & $\begin{array}{c}0.762^{\star \star \star} \\
(0.212)\end{array}$ & $\begin{array}{c}0.669^{\star \star \star} \\
(0.223)\end{array}$ & & & & $\begin{array}{c}1.140^{\star \star \star} \\
(0.389)\end{array}$ & $\begin{array}{l}0.890^{\star *} \\
(0.388)\end{array}$ & & \\
\hline FDI Inflows & & & & $\begin{array}{c}1.081 \\
(0.933)\end{array}$ & $\begin{array}{c}1.163 \\
(0.899)\end{array}$ & & & & $\begin{array}{c}0.482 \\
(1.309)\end{array}$ & $\begin{array}{c}0.704 \\
(1.185)\end{array}$ \\
\hline Portfolio Equity Inflows & & & & $\begin{array}{c}1.111 \\
(1.143)\end{array}$ & $\begin{array}{c}0.860 \\
(1.071)\end{array}$ & & & & $\begin{array}{c}2.741 \\
(2.237)\end{array}$ & $\begin{array}{c}2.089 \\
(2.155)\end{array}$ \\
\hline Other Debt Inflows & & & & $\begin{array}{c}0.733^{\star \star \star} \\
(0.230)\end{array}$ & $\begin{array}{l}0.635^{\star \star} \\
(0.248)\end{array}$ & & & & $\begin{array}{l}1.098^{\star \star *} \\
(0.392)\end{array}$ & $\begin{array}{l}0.851^{\text {** }} \\
(0.389)\end{array}$ \\
\hline Lag Dependent Variable & $\begin{array}{c}0.124 \\
(0.097)\end{array}$ & $\begin{array}{c}0.111 \\
(0.099)\end{array}$ & $\begin{array}{c}0.109 \\
(0.098)\end{array}$ & $\begin{array}{c}0.105 \\
(0.098)\end{array}$ & $\begin{array}{c}0.099 \\
(0.096)\end{array}$ & $\begin{array}{c}0.430^{\star \star \star} \\
(0.083)\end{array}$ & $\begin{array}{c}0.424^{\star \star \star} \\
(0.083)\end{array}$ & $\begin{array}{c}0.417^{\star \star *} \\
(0.089)\end{array}$ & $\begin{array}{l}0.432^{* * *} \\
(0.081)\end{array}$ & $\begin{array}{c}0.419^{\star \star \star \star} \\
(0.086)\end{array}$ \\
\hline US GDP Growth & $\begin{array}{c}0.228 \\
(0.145)\end{array}$ & $\begin{array}{l}0.253^{\star} \\
(0.144)\end{array}$ & $\begin{array}{l}0.260^{*} \\
(0.144)\end{array}$ & $\begin{array}{c}0.243 \\
(0.149)\end{array}$ & $\begin{array}{l}0.247^{\star} \\
(0.149)\end{array}$ & $\begin{array}{l}-0.238^{*} \\
(0.141)\end{array}$ & $\begin{array}{l}-0.207 \\
(0.146)\end{array}$ & $\begin{array}{l}-0.186 \\
(0.137)\end{array}$ & $\begin{array}{l}-0.210 \\
(0.152)\end{array}$ & $\begin{array}{l}-0.194 \\
(0.139)\end{array}$ \\
\hline Change in Terms of Trade & $\begin{array}{c}0.005 \\
(0.036)\end{array}$ & $\begin{array}{l}0.007 \\
(0.037)\end{array}$ & $\begin{array}{c}0.013 \\
(0.036)\end{array}$ & $\begin{array}{c}0.004 \\
(0.036)\end{array}$ & $\begin{array}{c}0.010 \\
(0.036)\end{array}$ & $\begin{array}{l}-0.070^{*} \\
(0.036)\end{array}$ & $\begin{array}{l}-0.067^{\star} \\
(0.037)\end{array}$ & $\begin{array}{l}-0.048 \\
(0.035)\end{array}$ & $\begin{array}{l}-0.060^{*} \\
(0.036)\end{array}$ & $\begin{array}{l}-0.046 \\
(0.035)\end{array}$ \\
\hline Policy Rate & $\begin{array}{c}-0.408^{\star \star \star} \\
(0.063)\end{array}$ & $\begin{array}{c}-0.422^{\star \star \star} \\
(0.065)\end{array}$ & $\begin{array}{c}-0.430^{\star \star \star} \\
(0.064)\end{array}$ & $\begin{array}{c}-0.418^{\star \star \star} \\
(0.067)\end{array}$ & $\begin{array}{c}-0.424^{\star \star \star} \\
(0.066)\end{array}$ & $\begin{array}{l}-0.101 \\
(0.072)\end{array}$ & $\begin{array}{l}-0.113 \\
(0.074)\end{array}$ & $\begin{array}{l}-0.131^{*} \\
(0.071)\end{array}$ & $\begin{array}{l}-0.115 \\
(0.078)\end{array}$ & $\begin{array}{l}-0.128^{*} \\
(0.074)\end{array}$ \\
\hline Foreign Reserves & $\begin{array}{l}-0.318 \\
(0.320)\end{array}$ & $\begin{array}{l}-0.301 \\
(0.321)\end{array}$ & $\begin{array}{l}-0.218 \\
(0.331)\end{array}$ & $\begin{array}{l}-0.303 \\
(0.334)\end{array}$ & $\begin{array}{l}-0.212 \\
(0.346)\end{array}$ & $\begin{array}{c}-0.893^{\star \star *} \\
(0.291)\end{array}$ & $\begin{array}{c}-0.871^{\star \star *} \\
(0.287)\end{array}$ & $\begin{array}{l}-0.645^{\star *} \\
(0.277)\end{array}$ & $\begin{array}{c}-0.903^{* * *} \\
(0.300)\end{array}$ & $\begin{array}{c}-0.669^{\star *} \\
(0.287)\end{array}$ \\
\hline Constant & $\begin{array}{l}6.502^{\star \star \star} \\
(0.917)\end{array}$ & $\begin{array}{l}6.605^{\star \star \star} \\
(0.927)\end{array}$ & $\begin{array}{l}6.693^{\star \star \star} \\
(0.917)\end{array}$ & $\begin{array}{l}6.502^{\star \star \star} \\
(0.986)\end{array}$ & $\begin{array}{l}6.550^{\star \star \star} \\
(0.976)\end{array}$ & $\begin{array}{l}1.782^{\star *} \\
(0.709)\end{array}$ & $\begin{array}{l}1.804^{\star \star} \\
(0.718)\end{array}$ & $\begin{array}{c}1.991^{\star \star \star \star} \\
(0.690)\end{array}$ & $\begin{array}{l}1.970^{\star *} \\
(0.821)\end{array}$ & $\begin{array}{l}1.992^{\star *} \\
(0.794)\end{array}$ \\
\hline $\begin{array}{l}\text { Observations } \\
\text { R-squared }\end{array}$ & $\begin{array}{c}136 \\
0.515\end{array}$ & $\begin{array}{c}136 \\
0.520\end{array}$ & $\begin{array}{c}136 \\
0.531\end{array}$ & $\begin{array}{c}136 \\
0.521\end{array}$ & $\begin{array}{c}136 \\
0.532\end{array}$ & $\begin{array}{c}136 \\
0.402\end{array}$ & $\begin{array}{c}136 \\
0.408\end{array}$ & $\begin{array}{c}136 \\
0.473\end{array}$ & $\begin{array}{c}136 \\
0.414\end{array}$ & $\begin{array}{c}136 \\
0.476\end{array}$ \\
\hline
\end{tabular}




\section{References}

Anderson, T. W., N. Kunitomo, and T. Sawa. 1982. Evaluation of the Distribution Function of the Limited Information Maximum Likelihood Estimator. Econometrica, 50(4): 1009-1027.

Fernandez-Arias, E. 1996. The New Wave of Private Capital Inflows: Push or Pull? Journal of Development Economics. 48: 389-418.

Baum, C., M. Schaffer, and S. Stillman. 2007. Enhanced Routines for Instrumental Viariables/Generalized Method of Moments Estimation and Testing. The Stata Journal, 7(4): 465-506.

Benigno, G., N. Converse, and L. Fornaro. 2015. Large Capital Inflows, Sectoral Allocation, and Economic Performance. Journal of International Money and Finance, 55: 60-87.

Blanchard, O., J. Ostry, A. Ghosh, and M. Chamon. 2016. Capital Flows: Expansionary or Contractionary? American Economic Review, 106(5): 565-569.

Blanchard, O., Ostry, A. Ghosh, and M. Chamon. 2015. Are Capital Inflows Expansionary or Contractionary? Theory, Policy Implications, and Some Evidence. IMF Working Paper 15/226. Washington D.C.

Bosworth, B. and S. Collins. 1999. Capital Flows to Developing Economies: Implications for Saving and Investment. Brookings Papers on Economic Activity 1: 143-69.

Broner, F., T. Didier, A. Erce, and S. Schmukler. 2013. Gross Capital Flows: Dynamics and Crises. Journal of Monetary Economics, 60: 113-133.

Caballero, J. 2014. Do Surges in International Capital Inflows Influence the Likelihood of Banking Crises? The Economic Journal, 126(591): 281-316.

Calvo, G. 1998. Capital Flows and Capital-Market Crises: The Simple Economics of Sudden Stops. Journal of Applied Economics, 1: 35-54.

Calvo, G., L. Leiderman, and C. Reinhart. 1993. Capital Inflows and Real Exchange Rate Appreciation in Latin America: The Role of External Factors. IMF Staff Papers, 40(1): 108-151.

Calvo, G., L. Leiderman, and C. Reinhart. 1996. Inflows of Capital to Developing Countries in 1990s. Journal of Economic Perspectives, 10(2): 123-139.

Chamon, M. and M. Garcia. 2016. Capital Controls in Brazil: Effective? Journal of International Money and Finance, 61: 163-187.

Chow, H. K. 2008. Managing Capital Flows: The Case of Singapore. Asian Development Bank Institute Discussion Paper No. 86. Asian Development Bank Institute. Tokyo, Japan.

Chuhan, P., S. Claessens, and N. Mamingi. 1998. Equity and Bond Flows to Latin America and Asia: The Role of Global and Country Factors. Journal of Development Economics, 55: 439-463.

Davidson, R. and J. G. MacKinnon. 1993. Estimation and Inference in Econometrics. Oxford University Press, New York.

Easterly, W. 2000. The Lost Decades ... and the Coming Boom? Policies, Shocks, and Developing Countries' Stagnation 1980-1998. World Bank, Washington, D.C.

Fleming, J. M. 1962. Domestic Financial Policies under Fixed and Floating Exchange Rates. IMF Staff Papers, 9:369-379.

Foong, K. K. 2008. Managing Capital Flows: The Case of Malaysia. Asian Development Bank Institute Discussion Paper No. 93. Asian Development Bank Institute. Tokyo, Japan.

Forbes, K. and F. Warnock. 2012a. Capital Flow Waves, Surges, Stops, Flights and Retrenchment. Journal of International Economics, 88 (2): 235-251.

Forbes, K. and F. Warnock. 2012b. Debt- and Equity-Led Capital Flows Episodes. NBER Working Paper Series No. 18329.

Fuller, W. 1977. Some Properties of a Modification of the Limited Information Estimator. Econometrica, 45(4): 939-953.

Ghosh, A., J. Kim, M. Qureshi, and J. Zalduendo. 2014. Surges. Journal of International Economics, 92(2): 266-285. 
Gochoco-Bautista, M. S. and D. Canlas. 2002. Monetary and Exchange Rate Policy. In The Philippine Economy: Development, Policies, and Challenges. Ed A. Balisacan and H. Hill. Oxford University Press. New York.

Gonzales, C. 2008. Capital Flows and Financial Assets in the Philippines: Determinants, Consequences, and Challenges for the Central Bank. Bank for International Settlements Paper No. 44.

Hahn, J., J. Hausman, and G. Kuersteiner. 2004. Estimation with Weak Instrument: Accuracy of Higher-Order Bias and MSE Approximations. Econometrics Journal, 7:272-306.

Hayashi, F. 2000. Econometrics. Princeton University Press, Princeton, New Jersey.

Intal, P. and G. Llanto. 1998. Financial Reform and Development in the Philippines, 1980-1997: Imperatives, Performance, and Challenges. Journal of Philippine Development, 45(1): 1-77.

International Monetary Fund. 2015. Philippines Selected Issues. IMF Country Report No. 15/247. International Monetary Fund, Washington D.C.

Kadiyala, K. R. and D. Oberhelman. 1992. Optimizing in the Class of Fuller Modified Limited Information Maximum Likelihood Estimators. Journal of Multivariate Analysis, 43:218-236.

Koepke, R. 2015. What Drives Capital Flows to Emerging Markets? A Survey of Empirical Literature. Institute for International Financial Working Paper.

Lamberte, M. 1995. Managing Surges in Capital Inflows: The Philippine Case. Journal of Philippine Development, 39(22): 43-88.

Lucas, R. 1990. Why Doesn't Capital Flow from Rich to Poor Countries? American Economic Review, 80 (2): 92-96.

Magud, N., C. Reinhart, and E. Vesperoni. 2014. Capital Inflows, Exchange Rate Flexibility, and Credit Booms. Review of Development Economics, 18(3): 415-430.

Martin, A. and F. Taddei. 2013. International Capital Flows and Credit Market Imperfections: A Tale of Two Frictions. Journal of International Economics, 89 (2): 441-452.

Milesi-Ferretti, G.-M. and C. Tille. 2011. The Great Retrenchment: International Capital Flows during the Global Financial Crisis. Economic Policy, 26(66): 285-342.

Mundell, R. 1963. Capital Mobility and Stabilization Policy under Fixed and Flexible Exchange Rates. Canadian Journal of Economics and Political Science. 29(4): 475-485.

Prasad, E., R. Rajan, and A. Subramanian. 2007. Foreign Capital and Economic Growth. NBER Working Paper No. 13619. National Bureau of Economic Research. Massachusetts.

Reinhart, C. and V. Reinhart. 2009. Capital Flow Bonanzas: An Encompassing View of the Past and Present. NBER International Seminar on Macroeconomics 2008.

Rodrik, D. 1998. Who Needs Capital-Account Convertibility? In Stanley Fischer and others, eds., Should the IMF Pursue Capital-Account Convertibility? Essays in International Finance 207. Princeton University, New Jersey.

Sangsubhan, K. 2008. Managing Capital Flows: The Case of Thailand. Asian Development Bank Institute Discussion Paper No. 95. Asian Development Bank Institute. Tokyo, Japan.

Wooldridge, J. 2001. Applications of Generalized Method of Moments Estimation. Journal of Economic Perspectives, 15(4): 87-100.

World Bank. 2001. International Capital Flows and Economic Growth. Global Development Financial Report. World Bank, Washington D.C.

Yap, J. 2008. Managing Capital Flows: The Case of the Philippines. ADB Institute Discussion Paper No. 91. Asian Development Bank Institute. Tokyo, Japan. 